\title{
THE MYTH OF BATMAN: INTRA- AND INTERDISCURSIVE TRANSFORMATIONS
}

\author{
Arina A. Kutovaia (a), Ekaterina V. Mikhailovskaya (b) \\ (a) Lomonosov Moscow State University. Moscow, Russia. Email: arina-kytovaya[at]mail.ru \\ (b) Lomonosov Moscow State University. Moscow, Russia. Email: morleyka[at]mail.ru
}

\begin{abstract}
The study focuses on the multimodal discourse of the superhero Batman which is viewed as both a corpus of texts about Batman and a process of their development in various media, such as comics, animation, film, video games. Since the launch of the 1930s' comics, the discourse has been incessantly developing, getting more and more intertwined with technology and new technology-based arts and industries. The evolution of the discourse can also be accounted for by the changing needs of the audience, as well as the shifts in the audience itself. At present, Batman discourse is comprised of a vast number of media texts, which intersect and influence each other. Each of these presents a new interpretation of the myth, based on the reesthetisization of basic constituent codes. The research aims to cover some aspects that define Batman as a cultural phenomenon of today, such as Batman as part of contemporary mythology and its relatability to the contemporary historical context, authorship in both the multimodal discourse and its media subdiscourses, intertextual and interdiscursive transformations.
\end{abstract}

\section{Keywords}

Batman; Myth; Multimodal Discourse; Media; Authorship; Intertextuality; Interdiscursivity; Comics; Animation; Film; Video Games

This work is licensed under a Creative Commons «Attribution» 4.0 International License. 


\section{МИФ О БЭТМЕНЕ: ИНТРА- И ИНТЕРДИСКУРСИВНЫЕ ТРАНСФОРМАЦИИ}

Кутовая Арина Александровна (a), Михайловская Екатерина Владимировна (b)

(а) Московский государственный университет имени М.В.Ломоносова. Москва, Россия. Email: arina-kytovaya[at]mail.ru

(b) Московский государственный университет имени М.В.Ломоносова. Москва, Россия. Email: morleyka[at]mail.ru

\section{Аннотация}

Предметом данного исследования является мультимодальный дискурс о супергерое Бэтмене, представляющий собой как совокупность текстов, так и единый процесс их порождения в различных медиа, таких как комикс, анимация, кино и видео-игры. На протяжении всей истории своего существования дискурс развивался во взаимосвязи с новыми технологиями и в пространстве связанных с ними новых видов искусства и индустрий, а также в прямой зависимости от состава целевой аудитории и ее запросов. Современный дискурс о Бэтмене представляет собой корпус различных медийных гетерогенных текстов, в каждом из которых миф о Бэтмене интерпретируется по-новому путем реэстетизации уже существующего набора основных кодов. Данные тексты взаимовлияют друг на друга как в пределах одного медийного субдискурса (интрадискурсивные трансформации), так и между различными субдискурсами (интердискурсивные трансформации). В задачу исследования входит рассмотрение таких аспектов мультимодального дискурса о Бэтмене, как его место в современной мифологии и соотнесенность мифа с современным историческим контекстом, проблема авторства как в мультимодальном дискурсе в целом, так и в субдискурсах, виды интертекстуальных и интердискурсивных связей.

\section{Ключевые слова}

Бэтмен; Миф; Мультимодальный дискурс; Авторство; Интертекстуальность; Интердискурсивность; Комикс; Анимация; Кино; Видеоигры

Это произведение доступно по пицензии Creative Commons «Attribution» («Атрибуция») 4.0 Всемирная 


\section{INTRODUCTION}

In spite of his rather long history, Batman still enjoys his popularity among the contemporary audience. Nowadays, there is no sign of a loss of interest in Batman myth, with new comic books, films, video games, etc. being produced and well received. The key to his survival for over eighty years is that Batman is changing as fast as the world around us, with each Batman text being a record of its own fleeting time. The flexibility of the theme, its ability to adjust to the requirements of the day lies at the core of the multimodal discourse of Batman which can be viewed as a general semantic and semiotic framework comprised of several media discourses: comics discourse, film discourse, video game discourse, animation discourse, etc., as well as minor Batman 'author' discourses, for example, Nolan discourse, Miller discourse, Burton discourse, etc. The core of the discourse is formed by comics, cinema, animation and video games, while fiction and audio plays stay at the periphery. Major changes that happen in the core affect the way the character is presented in all the other texts.

Since the 1930s, the discourse of Batman has been incessantly developing, becoming more and more intertwined with technology and new technology-based arts and industries. The evolution of the discourse can be accounted for by not only technological progress, but also by the changing needs of the audience, as well as the shifts in the audience itself. Nowadays, various texts (productions) connected with Batman as a character (or a brand-name) can be targeted at both wider and narrower audiences, depending on the industry, degree of complexity, level of intertextuality and other factors (Brooker, 2012b; Uricchio \& Pearson, 1991).

The discourse of Batman has so far proved to be 'an area of interactive experiment', with the audience actively participating in the creative process (Brooker, 2012b). What makes the discourse an even more intriguing field of investigation is its unfailing address to the agenda of the day, including political, social and psychological issues (Ackerman, 2008; Ip, 2011; Langley, 2012; Schopp, 2009; Toh, 2010; Bektemirov, 2019). These days, the general tendency to make multimodal stories about Batman more 'realistic', to shift from a superhero framework to the framework of modern drama, and to rely on the existing media templates, adds to its powerful appeal.

\section{METHODOLOGY AND AIMS}

Social and linguistic discursive studies has so far been centred mostly on verbal activity and, consequently, on homogeneous, monocode texts. However, with the development of technologies and a shift from verbal 
communication to the multimodal one, the number of multicode varieties of texts has been increasing rapidly. This trend has been recognized by linguists who proposed to extend the term text to those instances of human communication where language forms a strong relationship with the non-verbal codes, forming multicode messages based on synthesis of the verbal and the non-verbal (M. A. Efremova; A.G. Sonin; Yu.A. Sorokin; G. G. Slyshkin; E.F. Tarasov; A.N. Zaretskaya). It would not be too farfetched to suggest that such texts not only contribute to the already established and well-developed kinds of discourse, but may form some discourses by themselves. This may be especially true for those corpora of texts which were originally multicode (for example, comics), or which originated from multicode ones (for example, fiction based on comics). We might assume that these days such discourses are experiencing a period of rapid expansion, involving all kinds of monocode and multicode messages.

This proves to be true of texts targeted at wider audiences, since nowadays these tend to be predominantly multicode. The reason for this is not hard to find: texts which rely on the non-verbal, mainly visual, component are comprehended much faster than the verbal ones (S. McCloud; A.G. Sonin). Modulated by speech, they appear to be most widespread and far-reaching, with their audience being as wide as possible in terms of gender, age, race, regional and social identity, etc. Not infrequently such texts rely on the existing and well-known cultural codes, particularly precedent plots, or myths, adjusting them to the intellectual, psychological and technological demands of the audience/audiences.

In this paper an attempt is made to give a general overview of a multimodal discourse, outline its thematic scope, describe the typology of texts which constitute it, trace the main trends and conditions of its origins, evolution and further development. The discourse of Batman is viewed as the object of multidisciplinary study of semiotics, linguistics, cultural and art studies, and understood as cognitive, culturally bound process of conceptualizing, aestheticization and reaestheticization of cultural codes, manifested in a variety of mono- and multicode, mono- and multimodal texts. The need to unite all Batman texts under one umbrella term is preconditioned by the fact that texts about Batman, though diverse, retain their semantic and semiotic relatedness, forming a unified complex multimodal discourse.

Batman discourse is understood, firstly, as a corpus of texts about Batman, with their elements being in constant dynamic process of intersecting and influencing each other, and, secondly, as the process of recoding of the discourse's meanings in the emerging texts. The recoding of 
meanings is caused by the demand of a new, more up-to-date look at the old texts and themes which results in perpetual reinterpretation and reshuffling of the same events. The latter accounts for the generally intertextual, self-referential and interdiscursive character of the discourse.

\section{BATMAN AS PART OF CONTEMPORARY MYTHOLOGY}

The myth of Batman shows all the characteristics of a contemporary myth. Oriented at an archetypal story, it is a collective dream of modern society (Talal, 2019): while it can hardly boast any single authorship, it is a continuous story-telling process, supported and maintained by a crowd of authors and an equally vast audience of most active and energetic fans. Like any archetypal story, the myth of Batman

"unearths a universally human experience, then wraps itself inside a unique, culture-specific expression” (McKee, 1997, p. 4).

In terms of James Joyce (Finnegan's Wake), it presents a monomyth life and wanderings of a hero, normally following a common to all heroes' pattern of ordeals and tests (Campbell, 2004). The opportunity to identify ourselves with the hero is what never ceases to attract our attention to superhero myths, as

"heroes have qualities that we all can identify with and recognize in ourselves. They are propelled by universal drives that we can all understand: the desire to be loved and understood, to succeed, survive, be free, get revenge, right wrongs, or seek self-expression” (Vogler, 1998, p. 28).

By placing eternal human problems in the allegorical form of a fairy tale - a myth - we can draw attention to the core of the old problem. This kind of device was described by Viktor Shklovsky as 'defamiliarization' («остранение»):

\footnotetext{
"The end of art is to give a sensation of the object seen, not as recognized. The technique of art is to make things 'unfamiliar,' to make forms obscure, so as to increase the difficulty and the duration of perception. The act of perception in art is an end in itself and must be prolonged. In art, it is our experience of the process of construction that counts, not the finished product"1 (Shklovsky, 1925, p. 11).
}

Thus, to make old ideas and images look new, we must give them a new shape, present them in a new shell; to make the reader/viewer comprehend these ideas as unfamiliar and revelating, we must surprise him/

1 The quote is in the translation by Benjamin Sher. 
her by the so-far unknown, brand new form, rather than to make him/her recognize the already familiar shapes and patterns.

To attract such a continuous attention, which in case with Batman spans more than eight decades, a myth has to address not only truly universal issues but to explore the behavioural patterns - a contemporary myth is not a form of knowledge as it used to be in the ancient times, but rather a call for action (Sharipina, 2007). Superheroes are not just echoes of ancient ideas. As A. F. Losev aptly put it, mythology is not

"an immovable picture, albeit beautiful, but constantly developing human thinking which reflects the equally dynamic, restless and creatively developing historical reality" (Losev, 1996, p. 15).

Mythology is in constant evolution and reinterpretation. According to Roland Barthes, myth is not a relic of archaic consciousness, but part of modern culture that is semiotically realized in literature, comics, cinema, television, advertising, etc. (Barthes, 1996).

Just like ancient myths, contemporary myths investigate both the ideal and the ordinary (or perfect and imperfect) which make them so alive and stimulating (Losev, 1990). Man has always been keen on trying to achieve what cannot and will not be achieved - the ideal picture of the world, a kind of meaningful harmony of all the elements as it is seen by gods/a God. To overcome the ugly daily routine of life, man has believed to be in need of superpower - unnatural, unattainable qualities which would help him build a perfect world. As a result, comic superheroes can do things ordinary people wish they could do but cannot - they make human dreams 'come true', at least in story-telling.

Yet the elements of superhero myths can be mythical proper - those that cannot be found in reality (unrealistic), and lifelike - those that can be found in reality and are part and parcel of everyday human life (realistic). Lifelike traits help the recipient of the myth identify themselves with its characters. To become a myth, a story needs to contain components that can never be found in reality:

"mythical embraces everything which is unique, which happens rarely, if ever at all” (Talal, 2019, p. 40).

Most often, uniqueness implies deep and out-of-the-box observations about life, specific details and characteristics of a situation or person. Comics, especially superhero comics, fit the description perfectly, as almost everything concerning superheroes is larger than life: they are not just heroes, they are superheroes, who usually possess some superpowers; 
they fight not just villains but supervillains, who represent a far greater threat. Everything is taken to the extreme; life and death of the whole city/planet/planets/the universe depends on them. Superhero stories are mythical throughout, they are as not lifelike as it is possible, which might be the key to their everlasting popularity.

The dichotomies of the ideal vs. the ordinary and the mythical vs. the lifelike may intersect sometimes, yet unrealistic does not always mean perfect, and the realistic is not necessarily the embodiment of the imperfect. The combination of all these contradictions in myths leads to the fact that

"a myth is not a metaphysical construct, but a truly, materially and sensually created reality, which is at the same time disembodied from the ordinary course of action" (Losev, 1990, p. 61).

Comics, as well as many other manifestations of art, inherits a lot of symbolic units of mythical pratext (Kozlov, 1999). The cyclical nature and the presence of twin characters, as distinctive features of mythical pratext (marking its main characteristic - non-discreteness), are reflected in the serialized nature of comics (Ibid.). Batman's villains are in a way his counterparts - his 'twins', so to speak:

"Demonstrating everything from psychopathology to narcissism Batman's archenemies also offer twisted mirror images of Batman himself" (Hull, 2008).

Therefore, Batman himself becomes a deeper and more complicated character when compared with his 'twins' - they show the reader how close Batman really is to every of his villains. The mythical binary of good and evil is reversed into the question "what if?":

"Batman sees how his methodologies can go horribly wrong if he goes over a certain line. Penguin is bureaucracy gone bad. If Batman or Bruce Wayne let his foundation be used immorally he could become what Penguin is" (Ibid.).

The Nolan trilogy also shows a few mirrors: Ra's al Ghul is

"someone who our hero could become, had he succumbed to the temptation of revenge. Another villain of the movie - the Scarecrow - also serves this goal: just like Batman, he uses fear to suppress criminals, but, unlike him, he enjoys his power. In short, Ra's al Ghul is a manifestation of Bruce's rage, while the Scarecrow is a manifestation of his vanity. Wayne copes with both on his way to becoming a superhero" (Bektemirov, 2019, p. 41). 
Twins in mythology are not just opposites: they are also deeply connected, they share a very strong bond. Joker's crazy obsession with Batman partly shows this:

"I don't really think I can sit back and watch you die. It's selfish really, but we need each other. Life would be so boring without you. Who would I talk to? Who would really understand me?" (Hill, 2011)

Another mythological element, marked by the graphic form of a comic book, is zoomorphism which serves as a link between modern comics and ancient mythical texts. This connection is further determined by the gaming sphere of human culture (Kozlov, 1999) (an outstanding example of zoomorphism in comics is Maus by Art Spiegelman (1980-1991), where different nations are presented as different animal species (Spiegelman, 1996)). In Batman discourse animal metaphors play an important role: not only is the main hero linked to an animal (a bat), but other characters also have animal roles (Catwoman, Penguin, an organized crime group - the Court of Owls, etc.).

The mythical (in close connection to the gaming sphere) permeates the form, structure and content of comics, endowing the latter with artistry and giving a certain originality to its structural organization (which clearly demonstrates the game element of human culture). Due to the proximity to the gaming sphere, there is a game element in any part of the mythical that can ensure the destruction of the myth - demythologization (Kozlov, 1999).

The dichotomy of the ideal and the ordinary forms the bone structure of Batman discourse. The idea of Batman is the idea of perfection, which Bruce Wayne struggles to achieve and personify. To quote Alfred, the loyal butler: "Master Bruce has a very clear idea of human perfection towards which he constantly strives, you understand. The absolute physical mastery of the top martial artists, gymnasts or yogins, the logical and deductive skills of master philosophers, forensic scientists and detectives, the understanding, discrimination and moral clarity of ultimate Zen adepts... Need I continue?" (Morrison, 2010). This is what Bruce himself replies when told "You did all you could": "No. There's always more. I can push harder. I can be better" (Snyder \& Paquette, 2016). Bruce Wayne created a perfect figure - Batman:

Alfred: "Know your limits, Master Wayne."

Bruce: "Batman has no limits."

Alfred: "Well, you do, sir" (Nolan, Thomas \& Roven, 2008). 
Yet a myth would not be alive without the opposite component, the ordinary. In the Batman myth the imperfection of the world is striking, that is why the contrast between Batman and the criminal city is so visible. "If you're Batman and you're dealing in a world of Gotham City nothing is good. It's all dirty" ([Warner Bros. Entertainment], 2013). Batman struggles to make things better but he needs to fight the scum of the city - the criminal underworld and the corrupt police force alike: "You cannot get a working Batman if you have a police force that's doing its job" (Ibid.). More than that, Batman himself was born out of ugliness of life: a little boy Bruce Wayne could not cope with the sudden meaningless death of his parents and created Batman as the embodiment of perfection whose mythological forces fight with the imperfection and meaninglessness of the world: Batman will always win because he is Batman. His arch-enemy, Joker, on the other hand, represents the struggle to demythologize Batman. For Joker, everything is an accident that does not have any meaning:

"You think it all breaks down into symbolism and structures and hints and clues. No, Batman, that's just Wikipedia” (Morrison, 2010).

These two characters represent opposite forces: Batman is trying to achieve perfection which Joker denounces:

\begin{abstract}
"Batman says, philosophically, we can acknowledge an imperfect world. We can acknowledge that we have to step outside of social norms but that doesn't make the social norms meaningless. The Joker says the presence of random injustice means that there is no justice. The fact that innocence can be destroyed means there is no innocence. So your life is a joke. <...> It's a moral challenge. It's an intellectual challenge. And Batman can't let that go. The Joker isn't just threatening him physically. He's threatening the premise of Batman's existence" (Hull, 2008).
\end{abstract}

Justice is perfection that can never be fully achieved because it is the existence of injustice that makes Batman work - Batman is not needed in the just world. Batman, as a mythical character, seeks purpose in his life and it is what the audience may want to find in these stories.

\title{
AUTHORSHIP OR AUTHORSHIPS?
}

One of the keys to the phenomenal popularity of Batman as a character in different media industries and among the audience is its authorship/authorships. Although the original comic stories about Batman cre- 
ated by Bob Kane and Bill Finger in 1939 were the springboard for Batman character, there is no prototext, but a tradition maintained throughout time by individual authors/groups of authors. This means that each of the texts that comprise Batman discourse has an equal claim to originality and overall impact on the discourse with all the other texts of the corpus. This does not necessarily mean that all the texts and even media have been equally influential - quite the contrary. Still, narratives produced by different authors are equal in their right to contribute to the character, to develop the subject to this or that extent.

The serialized nature of Batman texts allows to explore different aspects of the Batman myth in different stories. Authors have the ability to concentrate on what is interesting for them, fully aware that other pivotal points will be (or have been) explored by other authors in other stories. For example, in Batman discourse the stages of the Hero's journey (Vogler, 1998) are not usually present all at once but explored bit by bit in various texts, not necessarily connected. Another curious thing is that in Batman discourse the Inmost Cave (Ibid.) has a slightly different meaning. In Batman Begins (Nolan, Thomas, Roven \& Franco, 2005) Bruce Wayne goes to a batcave to fight not a monster but his own fear of bats - he fights something within himself, not an external reality, yet the classical formula works and an additional layer of meaning is also there: Bruce conquers the fear and decides to embrace the monster he was afraid of. In various hero stories different stages may be explored to this or that extent; in Batman discourse nearly all of the stories take place when he is already a hero. Probably, that is why Batman discourse has been able to live that long: most characters are interesting on their way to becoming heroes and then disappear from view, yet Batman was already a hero from the start in 1939. He is compelling in being a hero, not only in becoming one.

There is, however, more to it. As it is often the case with the phenomena of popular culture, Batman discourse is largely influenced by the tastes and needs of the public and, particularly, its fans; in other words, is interactive throughout. Thus, for example, one of the characters, Jason Todd (the second Robin) was very unpopular among Batman fans, and eventually the authors of the comics created a grave situation for him in the plot, at the same time requesting the readers to vote by calling different numbers (the one for Jason to live and another one for him to die). More than 10000 votes were cast, with a few voices in favor of his death: in 1988, the character Jason Todd was killed by Joker in Batman: A Death in the Family (Starlin, Aparo \& O'Neil, 1988). This, however, did not prevent the next group of authors from giving the character another chance 
and in the 21st century, Jason Todd was resurrected: Batman discourse got an angry vigilante, much more cruel than Batman.

Nevertheless, the interest to the opinion of the fans has neither been stable, nor decisive. Tim Burton, when creating his films about Batman, paid little to no attention to what fans would think of his films, claiming that he was making a mass product. When approached by the fans who stated that they did not want Michael Keaton to play the lead, he said:

"This is too big a budget movie to worry about what a fan of a comic would say" (Uricchio \& Pearson, 1991, p. 184).

Yet sixteen years later, Christopher Nolan had a completely different view on the subject: the question of authenticity of the character was raised, several documentary films appeared that connected Nolan's trilogy to Batman comic books. Will Brooker (2012b) argues that only several Batman texts, mainly those created after 1986 (which is perfectly understandable because it is impossible to unite under one Batman interpretation all the other contradicting interpretations), were used as the source for the trilogy. Nolan's crew relied on them as the most famous and wellacclaimed ones: although not the only ones, they had won the unanimous love and support of the fans and, as such, could serve as a reliable, both artistically and commercially, source for The Dark Knight trilogy. As Round aptly put it, "studios now court fan approval, both in the terms [of] $<\ldots>$ advance screenings at conventions and so forth, but also more subtly, by promoting auras of authenticity and faithfulness around adaptations and products" (Round, 2014, p. 152).

Yet the problem of a faithful interpretation remains. As it is the case with Batman, fidelity becomes a rather abstract and conventional notion: it is flexible, dynamic, subject to changing over time - a faithful idea of what Batman is was different fifty years ago. Basically, a faithful notion of Batman at any given time is what contemporaries think Batman should be like. This makes the discourse extremely attractive both to authors who have the opportunity to express themselves without the fear that their interpretation will be considered 'unfaithful', and to readers who retain their elusive right to argue about different interpretations, without limiting themselves to the opinion of one 'true' author:

"'Truth' and 'reality' <..> are meaningless in relation to the Batman" (Brooker, 2012b, p. xi).

It would not be too far-fetched to suggest that the discourse is a sustainable creative process conducted by collective functionally differentiated 
authors (to use the term of G. G. Slyshkin and M. A. Efremova (Slyshkin \& Efremova, 2004)) of several generations, working in different media. The idea of fidelity in this process is then a matter of motifs and specific means of narration, rather than one 'true' story that has to be followed or violated:

"Batman Begins was faithful not so much to a source text, or even a set of source texts, as to an underlying mode of comics authorship through its creative reuse and revision of existing motifs and narrative strands" (Brooker, 2012b, p. 117).

The unique creative situation with the discourse of Batman results in the stable growth of the number of authors. This is largely accounted for by the great potential for development, backed up by careful monitoring of the audience's attitudes and wishes, as well as rapid development of multimedia technology. Thus, the discourse is a continuous dialogue of authors and audience spanning several decades.

\section{TWO POLES OF BATMAN}

The corpus of comic books about Batman is enormous - it is a collection of stories created at different times by different authors, where each writer has their vision of the hero: these differences may be striking enough to let the hero be identified by the name of the writer, like, for example, Miller's Batman, Snyder's Batman, even Nolan's Batman and Burton's Batman. However meaningful and compelling Batman's interpretations in other media may be, Batman is, first and foremost, a comic book character. Batman discourse is greatly defined by the medium of comics and its specific ways of building up the narrative. Symbolism of comics is embedded in the discourse where mythological inclination to symbols and specific expressive means (very laconic and symbolic narration) go hand in hand, that is why the medium of comics suits modern mythology so well.

From the very start, almost all the basic features of the character were established: a vigilante wearing a black costume with black bat wings (the first superhero to be given a demonic look) and fighting crime. Unlike many other superheroes, Batman was human and did not possess any superpowers; to combat crime he used his enormous intellectual potential and perfect physical shape. This is how Batman is described in the 27th issue of Detective Comics where he debuted: "The "Bat-Man", a mysterious and adventurous figure, fighting for righteousness and apprehend- 
ing the wrong doer, in his lone battle against the evil forces of society... His identity remains unknown" (Kane \& Finger, 1939a).

In ordinary life, Batman is Bruce Wayne, a millionaire playboy, who spends a lot of money developing new technical gadgets to be used by Batman. The story of the character is shown in one of the first issues: the 33rd issue of Detective Comics tells that Bruce witnessed his parents' murder when he was only a child. Shortly after that Bruce swore "to avenge their deaths by spending the rest of my life warring on all criminals" (Kane \& Finger, 1939b). The death of the parents became an essential part of Batman's story, told and retold in each successive comic book of the cycle, and a trigger of the plot: had his parents survived that night, he would never have had to become Batman. It is in the first issues that the character of Batman acquires psychological motivation: he is a superhero who wishes he did not have to exist - he would love to live in a world where crimes are not committed, yet, realizing it is impossible, he does everything in his power to reduce crime. It is interesting to note, though, that this character stands against all kinds of utopias and dictatorships (even when dictators are 'good' so to say); he believes in free choice. Detective Comics \#33 also shows that Bruce Wayne spent many years preparing his body and his mind for the task he is committed to, and explains the choice of bat as his sign: while he was thinking which kind of disguise would strike terror into the hearts of criminals, a bat flew in the open window; Bruce took it as an omen and decided to become Batman. These three fundamental motifs took only one page and a half in 1939. Much later, when realism and psychology began to make their way into comics, Bruce's childhood and especially youth were explored in greater detail (for example, Batman: Year One (Miller \& Mazzucchelli, 1987)).

There is, however, one more trait that distinguishes Batman from all the other characters: he does not kill. His aversion to weaponry, particularly to guns ${ }^{1}$, results from the tragic death of his parents he witnessed as a young boy (in any retelling of the story it is a gun). Batman does not want anyone to be killed or to feel the pain he felt when his parents were murdered. He protects innocent people from criminal acts and spares criminals because he believes he cannot be a judge - his job is to find the guilty and hand them over to the police: "Remember, we never kill with weapons of any kinds!" (Kane \& Finger, 1940b).

Almost all Batman stories are set in Gotham City (first introduced as Batman's place of residence in Batman \#4 (Kane \& Finger, 1940b)) - the

1 Yet this was not always so: in the first year of Batman's existence, he killed criminals and sometimes later he did something that he probably should not, for example, in Detective Comics \#572 (Barr, Roy \& O’Neil, 1987) Batman used a criminal as a human shield. Nevertheless, these are the exceptions generally considered to be not in Batman's character. 
most corrupt and criminal city in the USA (Batman: Year One (Miller \& Mazzucchelli, 1987)), which Batman/Bruce Wayne wants to make a better place. Bruce Wayne lives in Wayne Manor, which he inherited after his parents' death. The mansion is maintained by Alfred Pennyworth (who first appeared in comics in 1943), the Wayne family's butler and a friend. Batman is often helped by his assistant Robin (since 1940 more than four different Robins have appeared in comics) who originally was designed as a sidekick. Batman has an ally in the Gotham City Police Department Commissioner Gordon (this character being as old as Batman himself, both debuted in 1939).

Over the years, with more and more comics about Batman coming out, all this has become background knowledge or a shared code: everyone knows it, yet very few people have read the first printed stories about Batman. The reason is that over the years the same events of Batman's story have been written and rewritten multiple times, amounting to an extensive corpus of multicode texts which, taken together, constitute Batman discourse - a specific kind of discourse which takes more than just comics about Batman, but extends to incorporate other media (cinema, video games, etc.), which with time have become indispensable for understanding the character and its place in modern culture.

However, it would be a mistake to believe that there is some 'true' idea of what Batman is and what he is not. There is undoubtedly some shared concept of Batman, some basic features described above which 'signal' the character, but everything else may vary from author to author, sometimes developing and interpreting not what Batman is but rather what he could be. However, it would not be too far-fetched to say that all the interpretations of Batman have so far been located mainly between two poles, namely, a 'dark' Batman and a much more 'kid-friendly' Batman: less dark, more funny. The quintessence of the latter interpretation is to be found in the once popular 1960s TV series Batman (Dozier, 19661968): "The Adam West TV-show, which was a comedic take on Batman, was really popular for a couple of years. But when it went away, it went away like somebody turned off a light" ([Warner Bros. Entertainment], 2013). In the end, DC Comics had to either stop publishing Batman comics or find a way to revive the audience's interest in the character. Thus, in the late 1960s, comic books about Batman were taken "back to his darker roots" of Bob Kane and Bill Finger's initial interpretation (Ibid.) by Denny O'Neil and Neal Adams, whose comics marked the transition period which ended with the appearance of Frank Miller, who completely redeveloped the story, making it more 'adult', oriented to grown-ups rather than to kids. Miller's Batman graphic novels were intended as a profound 
commentary on such social vices as crime, corruption terrorism, deprivation, etc. The success of most famous Miller's The Dark Knight Returns (Miller, 1986) and Batman: Year One (Miller \& Mazzucchelli, 1987) highlighted both the potential of the art to challenge the spirit of the time and to focus in the most engaging manner on the most burning issues: according to Michael Uslan, "Frank Miller deserves a huge amount of credit for paving the way for everyone to a more sophisticated method of graphic storytelling, to a Gotham city we could all finally believe in, and to a new Batman that everybody could identify with and at the end of the day just believe in him" ([Warner Bros. Entertainment], 2013).

DC Comics tried very hard to eliminate funny Batman from the minds of the readers. In his book Hunting the Dark Knight (2012) Will Brooker applies Mikhail Bakhtin's theories of carnival to Batman discourse. In his opinion, "these theories intersect with the concepts of intertextuality and the model of Batman texts as a matrix" (Brooker, 2012b, p. 135). At the heart of Bakhtin's understanding of carnival lies a 'two-world condition' (Bakhtin, 1984, p. 6), the dynamic relationship between the official and the carnival: any formal event has its carnival opposite, a parody. Will Brooker states that "each of the main villains is Batman's circus counterpart, imitating and exposing the absurdity in his solemn obsessions" (Brooker, 2012b, p. 137). The 1960-s TV Show showed the viewers the funny carnival, and after that DC Comics tried to suppress the carnival by launching a dark Batman interpretation, just like carnival was suppressed in the culture of the seventeenth and early eighteenth centuries: "the grotesque related to the culture of folk humor was excluded from great literature..." (Bakhtin, 1984, p. 33).

The theory of Mikhail Bakhtin can also be successfully applied to the figure of the Joker - a clown with 'positive regeneration power' (Ibid., p. 38) that is later reduced to a minimum: his regenerating laughter is transformed into sarcastic laughter, and the clown becomes a sinister figure. Starting from the 1980-s the Joker is no longer a funny figure, but a terrifying laughing psychopath. The character of the Joker has been redefined and reinterpreted more than once. For example, in Batman (Guber, Peters \& Burton, 1989) the Joker is not really a madman, but rather a gangster, or even an infantile gangster (Bektemirov, 2019). In The Dark Knight (Nolan, 2008) this character was interpreted through the prism of the $9 / 11$ events, with the Joker becoming a merciless and ruthless terrorist. It is worth noticing that initially the Joker was not created funny: in his 'debut' issue (Batman \#1 (Kane, 1940a)) he killed several people and was described as 'diabolical' and 'ruthless'. In that issue the Joker's actions are also described as 'grotesque', which rings very much in tune with Bakhtin's de- 
scription of suppressed carnival: "The result is a broken grotesque figure" (Bakhtin, 1984, p. 53).

In spite of all the attempts to disguise the funny side of Batman discourse, to suppress the carnival, "even in his darkest, most military, macho and rational incarnations, carnival was never far from the surface" (Brooker, 2012b, p. 174). Frank Miller's works of the 1980-s grounded Batman very firmly in the grim world, close to reality. However, as Brooker puts it, "Even the most stripped-down, contained, individual utterance only achieves a 'tension-filled unity of language', haunted by the repressed voices of the others from which it inevitably borrows and with which it inevitably interacts" (Ibid., p. 150). In other words, it is impossible to fully suppress texts that are found temporarily inappropriate: trying to exclude some meanings, we only bring them to the light, give them a new life. Thus, here we observe the main characteristic of any discourse intertextuality and interplay of texts. Starting with Grant Morrison - who in his works made Batman's silly sides visible without destroying the seriousness of the character - DC comics stopped pretending that some parts of Batman's history never existed ${ }^{1}$. Will Brooker believes that it obviously made Batman's character deeper; Batman has his carnival side, his 'Jokerside', which needs to be kept in check: "a Dark Knight who struggles against his own Joker-like aspects is more interesting than a character without conflict" (Ibid., p. 177).

The story about Batman is more than eighty years old, with the comic books coming out regularly since 1939 and never interrupted. The myth of Batman has been reinterpreted more than once, the interpretations drifting between the two poles. Batman as the central figure of the discourse is everything he has ever been and that he can ever be, he is

"ridiculous and fearsome, a fatherly protector, a big boy scout, a grim vigilante and a gothic guardian" (Ibid., p. 153).

Yet the two poles are not limitations and can be joined by a third one where Batman will pose a danger for the world - such attempts have already been made.

1 Yet, there is a selective policy: some works are considered to be "true" and others are alternations of the story. 


\section{COMICS, ANIMATION, VIDEO GAMES: INTERTEXTUAL AND INTERDISCURSIVE TRANSFORMATIONS}

Comics as a medium lends itself to a very high degree of intertextuality, with each successive book in a series relying heavily on the previous corpus of comic texts, as well as showing the next step of development not always and not necessarily closely related to the previous parts. In general, such big comic book series as Batman are a constant repetition of the same events, seasoned with a pinch of a small number of new facts. It means that something new in comics is almost invariably 'wrapped' in something old. This understanding of the nature of comics brings us to Barthes' 'scriptor' (Barthes, 1977): it goes not only for Batman's own story (parents' murder, the appearance of a bat, etc.) but also for the frequent return of his villains. Most of Batman's major villains were introduced in the 1940s and still fight with Batman fairly often. Yet it does not mean that writers have no space for creativity in such circumstances or that they choose to repeat the same events in order not to bother themselves with inventing something new. We could say that Batman comic book writers express themselves through "a variety of writings, none of them original" (Ibid., p. 146). This, however, makes Batman as well as his opponents deeper and more thoughtful characters with every new story, as, like readers, writers see the characters differently and portray them differently (this is the case with Miller's Batman, Snyder's Batman, etc.).

Intertextuality of comics, due to its multicode nature, is either verbal or visual. Verbal intertextuality can be found in direct verbal quotes. For example, in Batman: Death of the Family (2013) Batman is told to retract his allies because they make him weak (in Joker's opinion): “...so that you may be reborn as the Bat-man this city deserves!" (Snyder \& Capullo, 2013). Batman became a proper name many decades ago, however, in the first two issues (Detective Comics \#27, \#28) of Batman comic books Batman was called "the "Bat-man"". Thus, the Joker's idea is enhanced by the reference: the Joker wants Batman to go back to his roots (to the beginning of his comic books), to abandon all his friends and allies he has acquired over the years.

Verbal intertextuality can also be found in those cases where the reader is reminded verbally of the events that happened in some other Batman texts. For example, Batman: Damned (Azzarello \& Bermejo, 2019) contains a great deal of allusions to the graphic novel Batman: The Killing foke (Moore \& Bolland, 1988). Batman: Damned opens with a vague reminder of the main joke from the graphic novel: 
"Reminds me of an old joke. Something to do with insanity an' a beam of light. Not much on the details. The punchline tho...? It's about a FALL" (Azzarello \& Bermejo, 2019).

This extract does not explain the original joke, the reader is supposed to know it. Yet Batman: The Killing foke is of such paramount importance for Batman discourse that it is hard to imagine that a person who reads Batman: Damned might not know Batman: The Killing foke.

Visual intertextuality in comics presupposes certain similarities between panels from different comic books. The similarities may be striking, like in Batman: Damned which took a lot from Batman: The Killing foke. In the latter, Joker is born when a man who lost everything in "one bad day" survives the chemicals he fell into. In Batman: Damned, Joker survives a lethal fall from the bridge and therefore is reborn, while Batman (who has just broken his code, deciding not to save a falling criminal) is dying on that same bridge because of knife wounds.

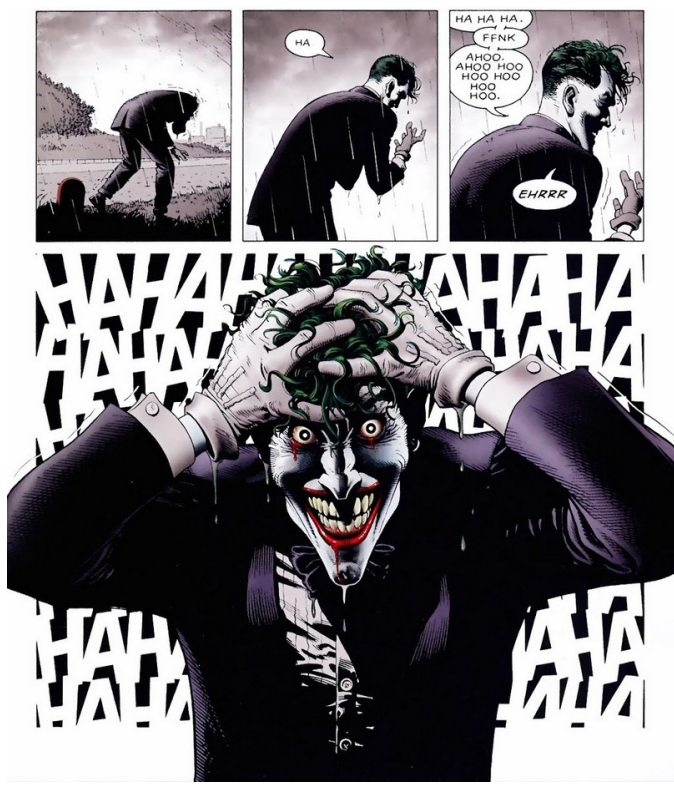

Fig. 1: Batman: The Killing Joke (Moore \& Bolland, 1988)

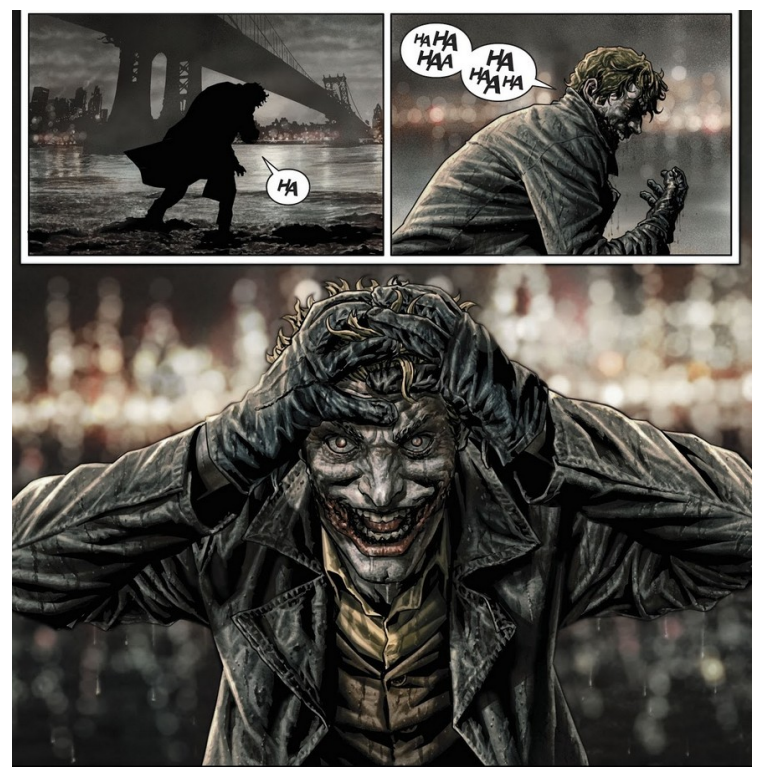

Fig. 2: Batman: Damned (Azzarello \& Bermejo, 2019)

1 The joke in Batman: The Killing Joke runs as follows: "See, there were these two guys in a lunatic asylum... and one night, one night they decide they don't like living in an asylum anymore. They decide they're going to escape! So, like, they get up onto the roof, and there, just across this narrow gap, they see the rooftops of the town, stretching away in the moon light... stretching away to freedom. Now, the first guy, he jumps right across with no problem. But his friend, his friend didn't dare make the leap. Y'see... Y'see, he's afraid of falling. So then, the first guy has an idea... He says 'Hey! I have my flashlight with me! I'll shine it across the gap between the buildings. You can walk along the beam and join me!' B-but the second guy just shakes his head. He suh-says... He says 'Wh-what do you think I am? Crazy? You'd turn it off when I was half way across!'” (Moore \& Bolland, 1988). 
The allusion is also transparent in Batman: Hush (Loeb \& Lee, 2003): the episode takes place right after the murder of Thomas and Martha Wayne, when young Bruce makes a vow to himself to fight criminals.

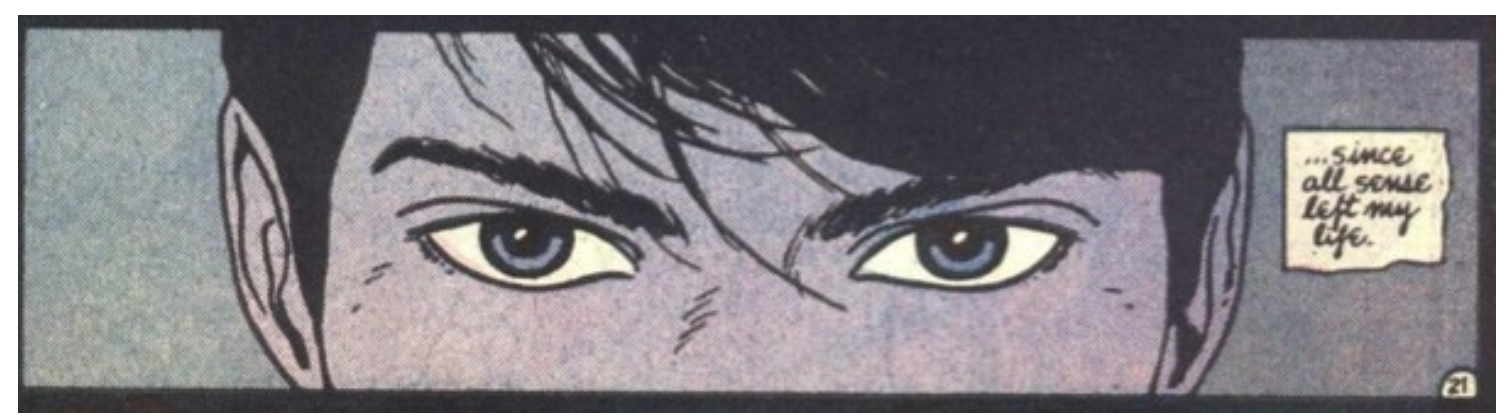

Fig. 3: Batman: Year One (Miller \& Mazzucchelli, 1987)

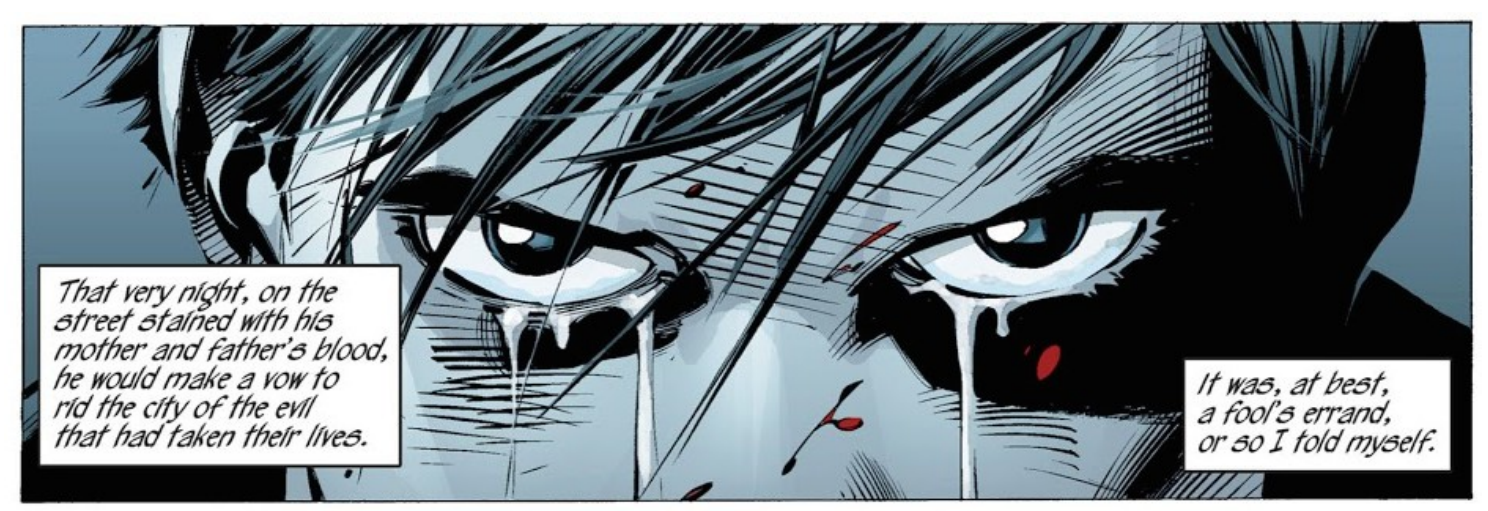

Fig. 4: Batman: Hush (Loeb \& Lee, 2003)

Batman: Year One explores Bruce's period of life prior to his becoming Batman. Almost any Batman text that touches upon Bruce's past refers to Batman: Year One, with Batman: Hush, being no exception. Despite the clear allusion, panels are still different: the second one is much more emotionally mixed. In Batman: Year One we see dedication in Bruce's eyes, in Batman: Hush not only dedication but also an enormous amount of pain and anger can be seen. Bruce is going to become the greatest crime fighter the world has ever seen but he is also a human who has his doubts and sorrows. This is an example of reinterpretation of the myth. The event remains unchanged, but Bruce's feelings are seen in a slightly different way.

Verbal and non-verbal intertextuality may go hand in hand. For example, in Batman: Hush one of the panels is very similar to the one of Detective Comics \#33 or Batman \#1 (they used the same panel). The intertextuality here is not only visual, but verbal, too: in 2003 the word 'Batman' had been a proper name for a very long period of time, but in this panel the authors used the definite article before 'Batman', clearly referring to the 
panel from 1940 (further in the graphic novel the definite article is not used before the name).

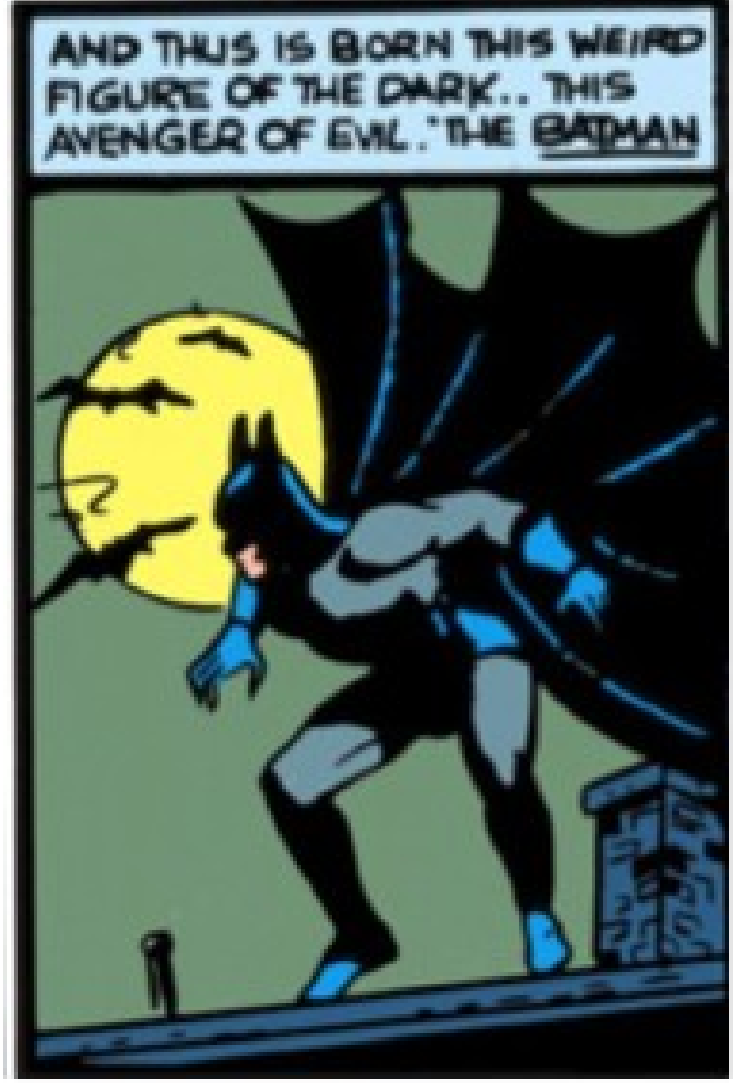

Fig. 5: Batman \#1

(Kane \& Finger, 1940a)

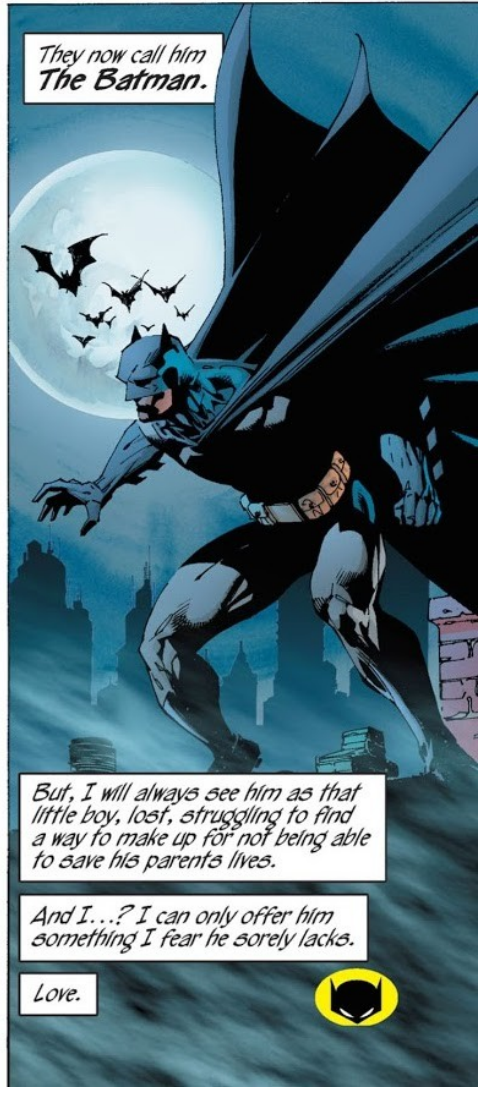

Fig. 6: Batman: Hush (Loeb \& Lee, 2003)

One of the key features of Batman discourse is its self-referentiality (in terms of D. Bordwell, 'self-consciousness'): all Batman comic books are in constant controversy with each other, highlighting different traits of the characters, offering this or that interpretation. However, intertextuality and self-referentiality of Batman discourse go far beyond the discourse of comics, to reach other media - cinema, animation, etc. All these, when dealing with Batman, become intertextual, self-referential and interdiscursive. That being the case, comics, cinema, video games, animation, books, audio plays, etc. freely refer to each other: not only do cinema and animation refer to comics, but comic books, in their turn, refer to other media, thus, for instance, in the panels of Batman: White Knight (Murphy, 2018) we may find a lot of references to different Batman films and TV series: Batman (Guber, Peters \& Burton, 1989) (fig. 19), Batman (Dozier, 1966-1968), Lego Batman (for example, The Lego Batman 


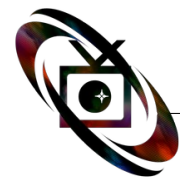

Movie (Lin, Lord, Miller, Lee \& McKay, 2017)), Batman: The Animated Series (Timm \& Radomski, 1992-1995), Batman Begins (Nolan et al, 2005), Batman: The Killing foke (Moore \& Bolland, 1988), to name just a few.
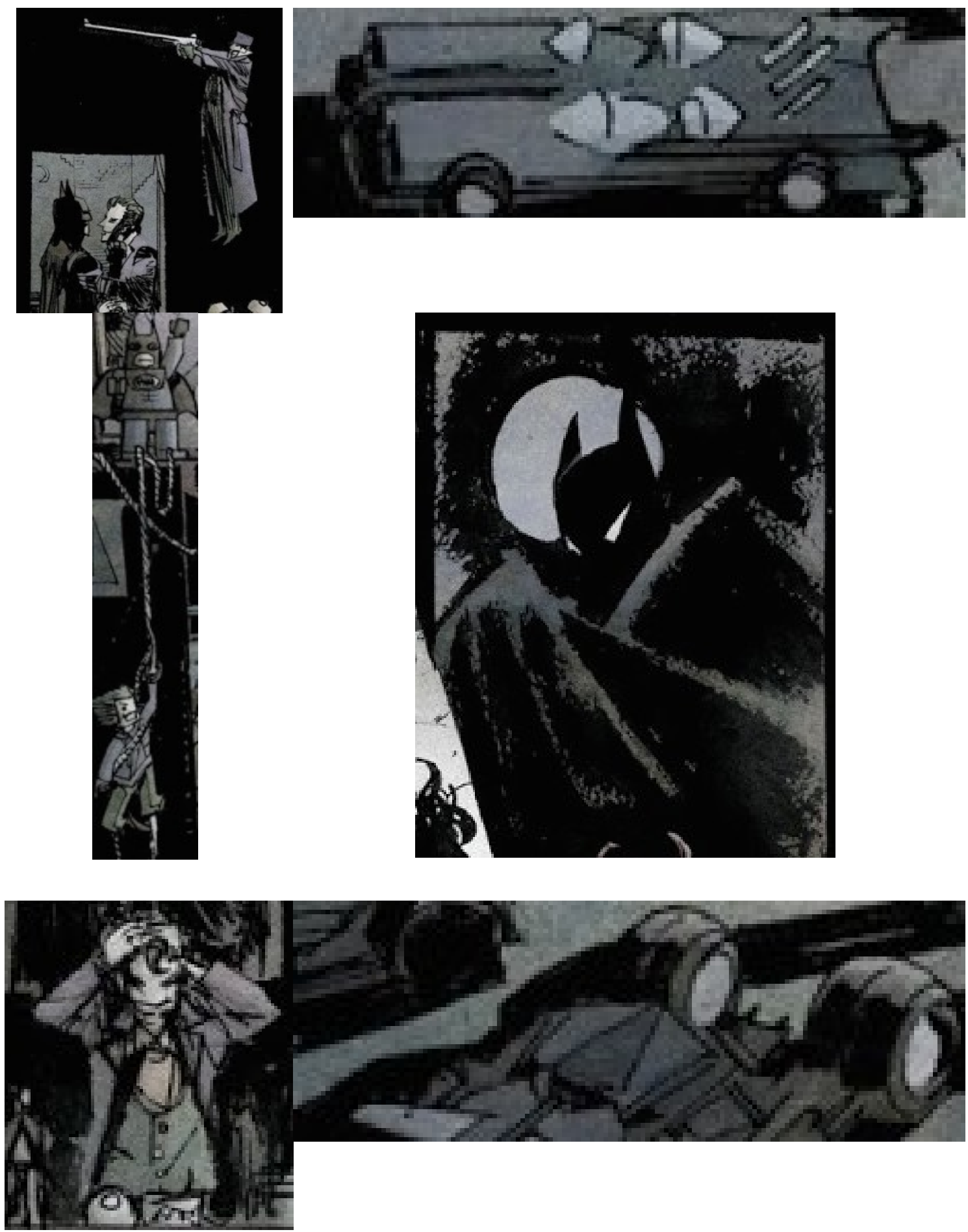

Fig. 7, 8, 9, 10, 11, 12: Batman: White Knight (Murphy, 2018) 
Showing a great deal of links to other Batman texts, Batman: White Knight stands apart from the mainstream comics, with certain deviations made for the sake of the story, and the skeleton changed a bit so it would better fit the purpose of the creators. It explores whether Batman does more good or harm, and is united with all the other texts of the discourse, reminding the reader that interpretations sometimes even oppose each other, yet it is still one character, explored from different angles. Batman: White Knight enters a vast net of Batman discourse smoothly and firmly: on the level of the plot it alludes to Batman \& Robin (MacGregor-Scott \& Schumacher, 1997), one of the least successful films about Batman ever created - Gotham city is threatened by the mighty weapon (created by Mr. Freeze) that can freeze the city. The creators of Batman: White Knight borrowed a lame-duck plot and transformed it into something intriguing, again illustrating Barthes' concept of scriptor: they combined the already existing elements of the discourse in a new shape and added their own vision. The presence of two Harley Quinns in Batman: White Knight is another major example of intertextuality.
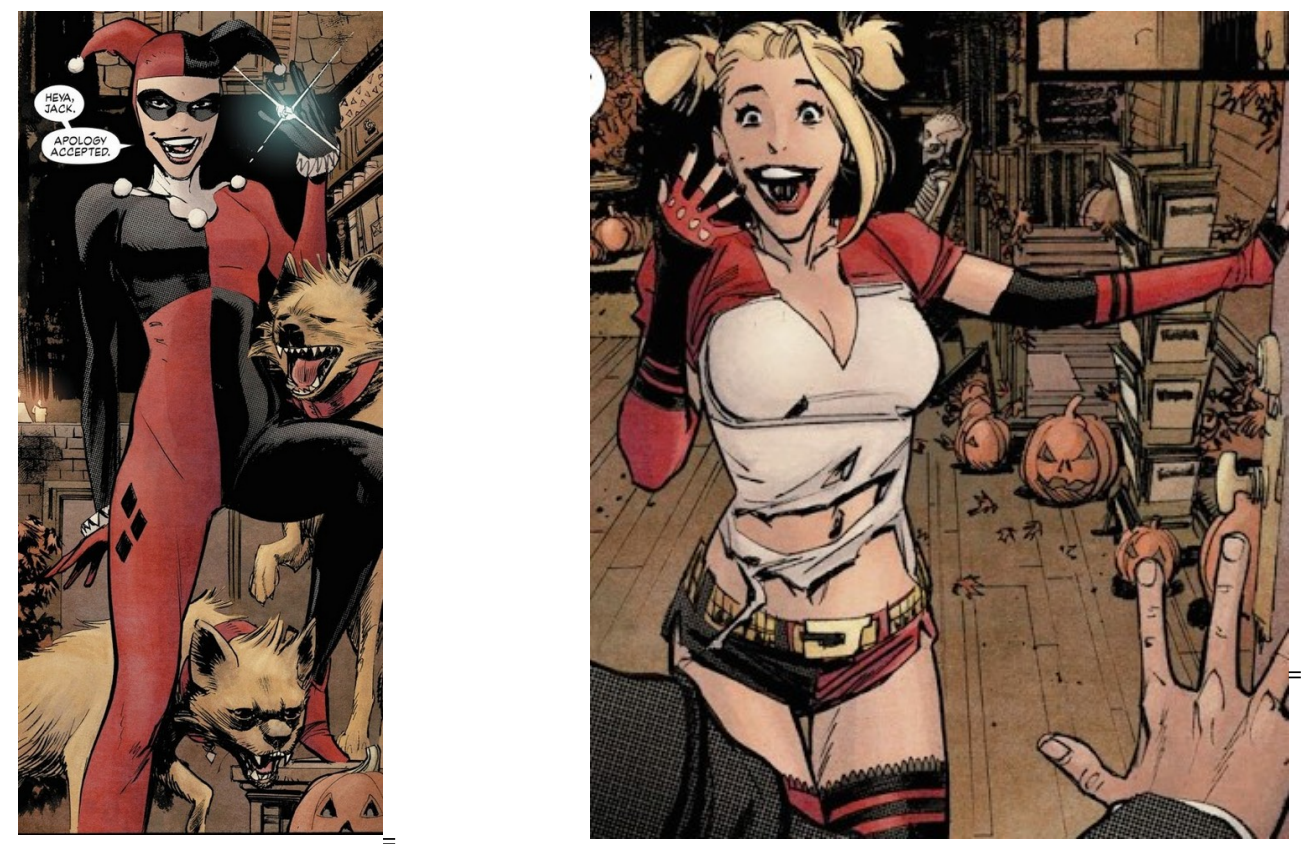

Fig. 13, 14: Batman: White Knight (Murphy, 2018)

The character was 'split' into two different versions relying on the history of the character. In Batman: The Animated Series, where Harley Quinn makes her debut, she wears a full cover suit and all she dreams of is to build a family with Joker. Yet over the years, in comics and films, Harley Quinn's appearance and character change: with her outfit getting more and more sexually appealing, she starts to have more psychological 
problems. Batman: White Knight created two different Harley Quinn characters, relying on these interpretations: the first Harley Quinn even comments upon the appearance of the other Harley: "And don't get me started on the clothes. Kind of a step back for feminism" (Murphy, 2018) - a very self-conscious remark. Batman texts estimate each other within the matrix of texts, bringing to the fore some problems like a common sexual objectification of the character's image. The creators of Batman: White Knight created a Batman text with intriguing alternative story, simultaneously imperceptibly commenting on the other texts of the discourse. This self-conscious approach to creation revives the previous texts in a new creation and allows to smoothly enter the net of texts and tie up to the old ones.

Animation is one of the most rapidly developing Batman subdiscourses. This is largely due to the fact that, being very close to comics in the principle of constructing visuals (both are pictorial), it can enrich the imaginary, colourful world of a comic book with visual motion and sound. In other words, what has so far been transcripted graphically with the help of size, font, punctuation, etc., now acquires its own sound - characters get their voices. This has been very much appreciated by the fans of Batman. The most famous voice actors in Batman discourse are Mark Hamill and Kevin Conroy, their voices being now strongly associated with the characters and defining even the way the readers 'hear' comic books: "Working with Mark Hamill and Kevin Conroy is fantastic for us. Like most people, you know, when you read the comics, these are the voices you hear of Batman and Joker" ([GameSpot], 2012).

This cannot but influence modern comics, with the sound images being now fully imprinted on the minds of the audience - a fact that both comics and animation has to put up with. While comics might orientate itself in the way it represents voice qualities of the characters graphically and the voice quality of Mark Hamill and Kevin Conroy as Joker and Batman respectively, animation has to reproduce the same voices in every successive production which might be problematic. Yet any shift from the established sound image might put a production at risk and fail to attract the attention of the viewers. Paradoxically, voice as part of the sound dimension turns to be 'common property' for both comics and animation, and, unless cinema has nothing more to offer in the world of sound, it will remain so for the time coming (Heath Ledger's and Christian Bale's interpretations of the voices affected the discourse, yet did not appear in other Batman texts).

As for video games, the main difference is their profound interactivity which allows the player to choose the next step. There are different types 
of Batman games: those in which your goal is to go through all the obstacles to get to the end to learn how the story ends (the Arkham series (Hill, 2009, 2011, 2015; Holmes \& Richer, 2013)) and those in which your decisions affect the story (the Telltale series (Mudle \& Stauder, 2016)). In terms of interactivity the second type is obviously more interesting (yet the first type may tell great stories as well, the Arkham series being a telling example). Is your Batman a cruel person or not? Will you beat the criminal up or only frighten him (even if it does not get you the information you need)? Will you trust Joker or not depending on his behaviour in the game? Will you try to save your friend, Harvey Dent, from becoming the Two-Face? In a video game the player acts, rather than watches the character to act: you are put into the character's shoes, and it is up to you to decide what to do. This social model allows the player to investigate $b e-$ havioural patterns even better than other media. This is an extremely appealing trick, as the gamer is invited and encouraged not only to watch an extraordinary person, but to become one. Moreover, the mere offer of several possible narratives within one provides the gamer with a unique opportunity to act as a co-author of the text, a co-creator and a character at the same time. In a video game, Batman is you, and it is up to you to choose what kind of person he is/you are.

Interactivity presupposes an active involvement in the creation of the story. The voices of the characters in video games are as important as in animation. Here animation and games usually intersect (the same actors voice the characters for animated films and for video games). In terms of narration, video games contain elements of animation and the recreation of time, motion, and space are basically the same as in animation and cinema on the whole - video games use complicated narration tools like flashbacks as well. However, interactivity adds an original twist to the recreation of these categories: the player is not only watching the characters moving, the player is moving the characters. Interactivity means more freedom in relation to these categories. Not only motion but space and time as well are influenced by interactivity: there is an opportunity to change the view angle and to stretch or shorten time of the game.

Audio intertextuality and interdiscursivity are very important for video games discourse. All of the four games of the series Batman: Arkham (except for Batman: Arkham Origins) were voiced by Kevin Conroy (Batman) and Mark Hamill (the Joker), who have been doing these characters for more than twenty years, being best known for Batman: Animated series (Timm \& Radomski, 1992-1995). Sefton Hill, Batman: Arkham City's game director, commented on the importance of voices in the game: "Batman: Arkham City is essentially a character-driven experi- 
ence, so the most important thing is to have the right voices for those characters" ([GameSpot], 2012). This is what the actors themselves said about their work and responsibility of being a part of the discourse: "I've been doing the character now for twenty years. The audience knows him as well as I do. They would know in a second if I did something... inauthentic" (Ibid.). Hamill's and Conroy's voices have grown to sound so authentic in the minds of the viewers that the new cast in Batman: Arkham Origins (2013) had to try very hard to imitate the voices of Hamill and Conroy. As a result, the voices are so similar that one might not even realize the change, as well as the replacement of the developer company (all Batman: Arkham games were developed by Rocksteady Studios except for this one). The creators of Batman: Arkham Origins did everything possible for the game to enter Batman: Arkham discourse smoothly and they achieved their goal: these four games are perceived as one story.

Video games are the most promising field of the discourse development since they provide a much higher degree of interactivity, when the audience stop to be 'mute consumers' of a product but become active participants and explorers of the theme. This caters for the practical realization of modern mythology, allowing the players to experience and to a certain extent develop the behavioural patterns better than in any other media, and to place themselves in the social model constructed by the game.

\section{BATMAN AND JOKER IN FILM: FROM MYTH TO REALITY AND BACK AGAIN}

Within the framework of the contemporary discourse about Batman, films seem to be as influential as comics themselves. During the last few decades a great deal of film productions about Batman have been released and got much acclaim among the audience, which is a good illustration of the fact that Batman has successfully crossed the borders between media. Nowadays, Batman film discourse has very strong influence on the discourse in general and it is mostly films that shape the way how most people see the character. Cinema affects the discourse of Batman greatly, yet it is not as loaded with references to other texts as comics. Films mostly use the same names of characters and share the same stories of their origin (with some changes). Although films use the same plot-skeleton as other Batman texts, every film-universe is separate from others. Basically, films more often than not serve as a source of borrowings for other texts; the number of references in them is quite limited. 
So far The Dark Knight trilogy by Christopher Nolan has been the subject of a whole series of studies (Ackerman, 2008; Asay, 2012; Brooker, 2012b; Ip, 2011; McGowan, 2015; Pheasant-Kelly, 2015; etc.). To avoid any repetition of what has already been described in the literature on the subject, we shall just dwell at some focal points. The Dark Knight trilogy by Christopher Nolan relies heavily on the notion of relatability (the term coined by Christopher Nolan) - the immersion of the hero into a contemporary context, which is made easily recognizable and obvious. The relatability of Nolan's trilogy largely rests on three factors: 1) address to the social agenda of the day, a faithful portrayal of a contemporary western city, with its vices and threats; 2) greater psychological depth and motivation of Batman and other characters; 3) well-articulated 'realistic' film style, based on the existing generic templates (action film, detective film, superhero film, martial arts film, mystery thriller, etc.)

The Dark Knight trilogy is a cinematic metaphor of the contemporary Western society, which has evoked a great deal of parallels and associations with the true historical events. The 'play with realism' that the trilogy offers only sharpens the discourse, bringing in a new dimension in the classical comic story.

It is no surprise that Nolan chooses to be quite conscious about global threats since the September 11 attacks made an indelible imprint on the mentality and worldview of the American nation, leading to the national frustration and rise of fear. It was only natural that this dramatic event very quickly got its representation in art, in comics and superhero discourse as well ${ }^{1}$. The USA was never the same after the $9 / 11$ attacks, so the questions raised by art also changed. Will Brooker in his article The Dark Knight Rises articulates one of the post-9/11 world's questions: "how far can we go in fighting terrorism with its own tools before we become terrorists ourselves?" (Brooker, 2012a). It is one of the topics touched by The Dark Knight (Nolan, 2008). Batman Begins is also a post 9/11 film, yet in the second film of the trilogy allusions are much more explicit.

Batman turns to be one of the most suitable characters to highlight the problem because despite being an outlaw, Batman very firmly distinguishes himself from criminals (therefore the question of a border between being outside the law and being a criminal is pivotal in this discourse). He does not always act by the book but he draws the line be-

1 To name a few examples, The Amazing Spider-Man Vol.2 \#36 (Straczynski, 2001) (called the "Black Issue" because of its completely black cover), released in November 2001, responded directly to the attack. In December 2001, a collective work Heroes: The World's Greatest Super Hero Creators Honor The World's Greatest Heroes 9-11-2001 (Busiek et al, 2001) was published. Indeed, the greatest superhero creators participated in this work's creation (Stan Lee, Alan Moore, Paul Dini, Neil Gaiman, etc.). From 2002 to 2004, Art Spiegelman published his comic strips called In the Shadow of No Towers (Spiegelman, 2004). 
tween himself and the evil he fights with. Batman has a strict moral code that he cannot break, he always verifies his actions in accordance with it. He has self-imposed restrictions to guide his war on crime (in this case, probably, war on terror) not to become a villain like in Harvey Dent's selffulfilling prophecy: "You either die a hero, or you live long enough to see yourself become the villain" (Nolan, 2008).

In The Dark Knight Batman is forced to push the boundaries of his moral code because of the Joker's threat. Many see this to be a reflection of war on terror, Bush and Cheney's policy after 9/11. Thus, some researchers tend to believe that Batman in the film is on the side of the Bush administration, justifying their counter-terrorism policy (for example, Ackerman, 2008; Ip, 2010). However, this can hardly be confirmed if we take a closer look at the film. Batman, instead of legitimizing violations of his moral code in his own eyes, exiles himself at the end of the film: "We vicariously enjoy Batman's brutality against Joker, trusting him to eliminate the threat by any means necessary; but in doing so, he becomes a monster. In the film's final scene, Batman exiles himself, shouldering responsibility for his actions and accepting that he must be cast out from Gotham City" (Brooker, 2012a). He understands and accepts that what he has done can hardly be justified by the circumstances.

There are two more issues, closely connected to the war on terror in The Dark Knight: the surveillance and the interrogation with torture. It could be said that the surveillance somehow helped (which is believed to be an allusion to the NSA surveillance program run after 9/11), yet the surveillance in the film was a temporary decision. Steve Biodrowski states: "Unlike the Bush administration, it is clear that Wayne does not anticipate an unending war that will permanently justify an expansion of his powers" (cited by Brooker, 2012b, p. 203). Also, when creating it, Bruce laid the possibility of destruction in the system and gave access to it to Lucius Fox, who opposes the idea of "spying on thirty million people" and characterizes the program with three precise adjectives: "Beautiful. Unethical. Dangerous" (Nolan, 2008).

The idea of cost of the terrorist's capture is raised not only in the discourse about the film but in the film itself:

- "With half the city feeding you sonar, you can image all of Gotham. This is wrong.

- I've gotta find this man, Lucius.

- At what cost?

The database is null-key encrypted. It can only be accessed by one person.

- This is too much power for one person.

- That's why I gave it to you. Only you can use it" (Ibid.). 
The temporality of such measures is reinforced by Fox's words: "I'll help you this one time. But consider this my resignation. As long as this machine is at Wayne Enterprises, I won't be" (Ibid). Batman deliberately limits his own access to the program because it is hard to give up the power once you have it.

Whether the surveillance proved to be a useful tool or not is questionable (it failed to show that the real threat was doctors, not clowns), yet the interrogation with torture (again, a possible reference to Bush and Cheney's policy) did not lead to anything at all. Despite the interrogation with torture, Joker gave Batman exactly the information Joker wanted him to know, and exactly when he wanted to give it ("You have nothing, nothing to threaten me with. Nothing to do with all your strength" (Ibid.)). When Batman threw Maroni from a height to get information, it was in vain, as the criminal did not know anything. The same happened when Harvey Dent threatened to kill Thomas Schiff. It means that the fight against terrorists by their own methods in the film did not work. It seems that The Dark Knight questions the policy if not criticizes: "The Dark Knight is more likely to ask the question of whether such means can be used to achieve such ends than to give a chewed and unambiguous answer" (Bektemirov, 2019, p. 42).

The layered narrative of Christopher Nolan's films perfectly fits the modern agenda. Different interpretations and levels of perception deepen the story, making it almost impossible to see the world as black and white: "What these curious potential parallels reveal is that the film's allusions are all conflicted and muddled, and as a result the film reflects the muddled collective subjectivity of the post-September 11 American culture, a subjective space in which we cannot know who is who, what constitutes the hero or the villain, what makes one a criminal, or what vision of justice we should embrace" (Schopp, 2009, p. 277).

In terms of form, The Dark Knight trilogy disrupts the tradition of a serialized format established by previous fragmented comic and film narratives, building up a coherent and consistent cinematic narrative, revolving around the personal story of Bruce Wayne as Batman from beginning to end: Batman comic books are a never-ending adventure, while The Dark Knight trilogy is a complete story, "beginning, a middle and an end" (Goldberg, 2012). At the centre of Nolan's trilogy is not politics or thousands of possible interpretations but rather a biography - a story of a man: "Every film has to be driven by story and story's driven by people, by characters, by the human face and what we recognise in it and what we're attracted to and what we hope for for that character. That relatabil- 
ity is what drew me to Bruce Wayne's story because he is a relatable character who is extraordinary" (Ibid.).

The relatability of the Dark Knight trilogy paved the way to foker (Phillips, 2019) - probably the most realistic text Batman discourse has ever produced. Creating a setting where Batman does not exist and Joker is not Joker but an ordinary person, shifts the discourse from the superhero genre to a much more 'realistic' psychological drama, a far cry from any superhero story. Already at the post-production stage, the film was criticized for justifying the killer. However, the goal was to draw public attention to the origins of crime, its social preconditioning and spread. The social grounding of the story has made it possible to investigate the problem of crime (be it mythical or real) by means of cinematic drama, which enables the viewer to treat the story as a metaphor of real urban crime. The story of Joker in foker is bound to explain how society triggers the mechanism of multiplying crime and criminals.

Joker has a long history as a DC character, and he is also one of the most archetypal figures. "The image of the jester, trickster, Harlequin is one of the key characters in the world culture. According to one of the versions, Harlequin is initially head of the Wild Hunt, knocking travellers off the right track. Another prototype of the eternal rogue is the god Hermes, the patron of wanderers who also guides souls to the afterlife. Generally speaking, the Joker jester is associated with transgression, a transition state, a carnival space, where everything turns upside down and the laws no longer work. Therefore, even the kindest clown has the inherent potentiality for horror and an element of devilish ambiguity" (Gorelikov, 2019, p. 21).

Joker as a DC character was created in 1940: a ruthless murderer, he was equal to Batman in mind power. When comics in the 1950s were subjected to strict censorship (the Comics Code Authority), the character became less murderous, more clownish. Only in the 1970s (along with the general "darkening" of the discourse) was he allowed to go back where he started: a smart deadly villain who purposefully reflects Batman as if in a crooked mirror.

Like Batman, Joker has many different interpretations. In various media, Joker has so far been presented as a psycho and a criminal mastermind, a gangster and a terrorist, a murderous clown and a philosopher. Heath Ledger's Joker in 2008 made the whole world look more closely at one of the most captivating villains ever created, and motivated Todd Phillips to offer a new interpretation of this eternal (or, rather, infernal) character of culture. 
In foker the story is set in the Gotham of the 1980s. Utility workers are on strike, mountains of garbage in the city are growing, resembling the New York of 1981 ([Warner Bros. Entertainment], 2020). Arthur Fleck, an unsuccessful comedian, lives with his sick mother. He works as a clown in a small entertainment agency and dreams of a career as a standup comedian. Arthur suffers from a neurological condition causing sudden uncontrollable laughter, which makes him dependent on taking strong medicine. The film shows the clash of a mentally unstable person with an indifferent and sometimes cruel society: hooligans beat him in an alley, his colleagues make fun of him, three young guys bully him in the subway. At some point Arthur ceases to passively accept these humiliations and violently takes revenge with a gun, unexpectedly discovering that he is alive, he exists, and "people are starting to notice". The slow glide of the protagonist into the killer is interspersed with hallucinations that immerse the viewer in the world of this deeply unhappy little man who was just trying to bring a little joy to this world. The story unveils against the backdrop of uprisings of the 'poor' against the 'rich' (which easily echoes the Occupy Wall Street movement). The clown mask suddenly becomes the face of an uprising, which Arthur inadvertently started.

The film can be roughly divided into two parts: the more lifelike one and the more mythical one. The first part of the film tells a story of a poor, lonely and mentally unstable man who seems to face the same problems that millions of viewers face in their everyday life: he takes care of his sick mother, sees a psychotherapist regularly, makes his ends meet by working as a party clown and dreams of becoming a successful comedian. The realism of this part largely depends on the sense of place which the filmmakers skillfully create: the places Arthur inhabits are deliberately made to look like urban slums, easily recognizable by residents of big cities. This part has nothing particularly mythical in it; it reads as a realistic story about a man with mental disease struggling to find his place in the world.

Only when the viewer gets completely immersed in the reality on the screen and has a strong feeling of identifying it with his/her own, does the mythical part begin. A part of the trickster archetype, Joker endows Arthur Fleck with his mythical power; the viewer does not expect Arthur to have such strength and dedication, yet when he becomes Joker, his whole persona is changed. He takes off all the masks the society has put on him and embraces this mythical power to become a myth himself: now he can easily run away from the police or walk away from them without hiding, he can disregard social norms and do whatever he likes 
(like dancing anywhere he wants when he feels like it ${ }^{1}$ ), and even when caught he does not think about it but enjoys watching the riots on the streets, like he is not a person anymore but an idea.

Arthur ceases to be a man and becomes a myth; he is not trapped in his life anymore, he is free. The viewer gets a breath of fresh air together with the protagonist, feels his long-anticipated freedom, which means the identification is working: the viewer feels Arthur's desperation, aches for him. For the time of the film, the viewer becomes the man who gets beaten and humiliated for no reason, who is tired of the ugliness and hypocrisy of the world which resonates with every viewer. The lifelike part allows the audience to identify with the character heavily, while the mythical part erases individual traits, the story becomes universal. This is probably what stands behind the phenomenal success of the film ${ }^{2}$ : the mythical touch in foker allows to convey universal and at the same time topical ideas to a large and varied audience.

Joker and Batman have always been tied up, the former being the clown nemesis of the latter. The characters are defined by each other and represent polar opposites (mythical twins): hero - villain, darkness brightness, frown - smile, saviour - killer, etc. In foker, another dichotomy comes to the fore: rich - poor. It is not new to portray Joker's past in this light, yet this feature has never become a distinguishing one for these characters. The scene where Arthur comes to Wayne manor to see Bruce almost literally reflects the meeting scene of the prince and the pauper in Mark Twain's The Prince and the Pauper. In Foker, the social distance between the characters is as transparent as in the book set in the 16th century. In the film there is a possibility that they are brothers, which unites them even stronger. In the meeting scene Arthur sees in Bruce his own reflection and tries to make him smile (like he has always been taught to do). More than that, to emphasize this twin bond between the characters, the creators add some context, changing the name of the film Bruce and his parents went to see from the traditional The Mark of Zorro (either the classic 1920 version (Niblo, 1920) or the 1940 sound remake (Mamoulian, 1940) to Zorro, The Gay Blade (Medak, 1981), which perfectly fits the timeline of the story (1981) and intertextually connects Joker and Batman as mythological twins: this Zorro story is about twin brothers, one of them being a classic vigilante and the other wearing a colourful, almost clownish costume.

1 "[The dance in the bathroom] is an effective way of illustrating the beginning of a transformation, with grace that kind of comes out of nowhere. You kind of feel that he has it in him. $<\ldots>$ There is a certain elegance and a certain romance $<\ldots>$ There is music in him, so to speak. But that's the first time we really see it come out" ([Warner Bros. Entertainment], 2020).

2 It is the first R-rated film in history that was able to gross over $\$ 1$ billion. 
The lifelike and the mythical parts of the film are mostly demarcated by the scene in which Arthur climbs into the refrigerator. It is difficult not to notice the mythological shift; hence one of the most common interpretations of the film is that Arthur Fleck died in the fridge and everything we see after that scene happens only in his imagination, where he is truly free to do whatever he wants, where he can pursue his justice, where he finally stops wearing a socially acceptable mask and shows the world his true face - Joker. This theory is easier to accept than the one that Arthur was actually invited to his favourite show, ran away from police, etc. The reasons for this are understandable: too many lucky coincidences are at odds with the realistic approach - it is accepted in a convention of a myth yet is perceived to be highly 'unrealistic' in a more down-to-Earth narration ${ }^{1}$. Although the Joker of the film is as close to reality as it is possible for now, it would be unwise to deprive the character of his elusive mythical character, as it is the myth that elevates a drama of an ordinary man to the level of a universal generalization - Joker becomes a powerful social metaphor, a symbol of today:

\begin{abstract}
"the cult around Batman's enemy has been building up for decades and is now rethinking itself. Joker is a film, a speculation on an intuitively clear, well-developed mythology of comics from a completely different standpoint. Joaquin Phoenix endows his character with a personality and a past, only to destroy them, to make human traits blurred and turn into an eternal frown" (Gorelikov, 2019, p. 20).
\end{abstract}

foker is a story told by an unreliable narrator, which totally depends on the point of view of the protagonist. Quite a few scenes may be treated as happening in Arthur's mind (these scenes and a lot of other features found in the film transparently allude to The King of Comedy (Milchan \& Scorsese, 1982)). The viewers cannot help but wonder if other scenes are imaginary as well. However, in recent years more and more films have been released that erase the border between reality and imagination. Films are made to be seen, and the question such films may pose is: does it really matter whether something is 'real' or not in the convention of the film if the viewer can still experience it? Therefore, the notions of objectivity and subjectivity in such narrations become less important: selfidentification of the viewer with the character makes his feelings experienced as real.

1 People mainly perceive lucky coincidences to be 'unrealistic', despite the fact that all sorts of coincidences may be found in real life; the same situation is observed when people perceive a 'happy ending' as a convention, while an 'unhappy ending' is more associated with 'realism' (MacDowell, 2013). 
As it has been already stated, the majority of Batman texts are intertextual, foker being no exception. Relying on comics, the filmmakers nevertheless wanted to "make something that felt grounded in reality" ([Warner Bros. Entertainment], 2020) and deliberately "departed from a lot of the comic book things", "made up a new character", "gave him this name" and "chose it out of the blue" (Ibid.). As the name Arthur Fleck did not appear in the comics, they tried to recreate a character from scratch, without burdening him with too many additional meanings, yet fully realizing the possibilities of the discourse for such experiments:

\footnotetext{
"There are many ways to look at the movie. He might not be Joker. This is just a version of a Joker origin; it's the version this guy is telling in this room at a mental institution. I don't know that he's the most reliable narrator in the world, you know what I'm saying?" (Ibid.).
}

Joker, as part of Batman discourse, is one of the universes, a separate story (like the majority of Batman texts); thus, by trying to separate the film from the rest of the discourse, the director only ties them together. Todd Phillips's statement that it is $a$ version of the character echoes Batman: The Killing foke: in the graphic novel Joker declares that sometimes he "remembers it [his past] one way, sometimes another" (Moore \& Bolland, 1988) and that he prefers his past "to be multiple choice" (Ibid.). Thus, the whole film can be viewed as just one of the versions Joker tells his psychiatrist at Arkham. Stating that this is one of the possible versions of the character, the creators did not break the bond between various Jokers but, on the contrary, reinforced this feeling of all-pervading intertextuality and that texts in this discourse are created by collective functionally differentiated authors. Also, unreliability is what Joker is famous for in comics as well, therefore, even this unreliable narration has to do with the character on the whole, not only this specific film.

Although foker appears to be quite independent from the overall Batman discourse, it is impossible not to notice the graceful treatment of the Joker story with the mythical antagonist of Batman transforming into an almost real person, for the first time humanizing the clown mask to this extent. Still, intertextuality allows to notice more details. At the end of the film, Joker laughs because he came up with a joke but when the psychiatrist asks if he wants to tell it to her, he answers: "You wouldn't get it" (Phillips, 2019). To understand the joke one needs to live Arthur's life (like the viewer did, watching the film): our lives are meaningless because everything (good and bad, justice and injustice) is random, and the only thing that is left is to laugh at it, not trying to control uncontrollable things. The meanings that were piling up in the discourse for decades 
have been transferred into the film without clear explanations but with the possibility for the viewer to find them. The film indirectly gives the viewer the answer: "I thought my life was a tragedy, now I realize it's a fucking comedy" (Ibid.), which adds up to the distinction between the two parts of the film: in the first part Arthur considers his life to be a tragedy and he suffers just like a tragic character is supposed to suffer, in the second part the attitude changes: from now on his life is a comedy and he is the main comedian - "He who is locked up in a tragedy pities himself, he who has chosen comedy pities no one" (Tsvetkov, 2019, p. 49).

foker is inside and outside of Batman discourse at the same time. The film shows new facets of their eternal confrontation by making the man, who is to become Joker, the narrator. It shows the cracks in society that are not that visible from the perspective of the hero. The villain has a story to tell and the world is ready to listen. foker is independent to such an extent that we could even talk about foker discourse, yet in conjunction with Batman both characters get much more significance than separately (at least, over the course of 80 years, this has been so). Great heroes are defined by great villains, and Batman and Joker are two sides of the same coin: Batman is the order and Joker is the chaos; Batman wears a mask to hide his true identity while the Joker mask is the true face. foker allows to look at this duet in the new light: Batman is an 'aristocrat' and Joker is a 'commoner'; it inevitably affects their lives.

foker (2019) by Todd Phillips, made in the genre of psychological drama, is a step forward towards more relatability of the discourse of Batman. It expands the discourse to the point where it stops to be a superhero story and begins to explore unrelated to the superhero genre issues, such as the origins of crime and social deprivation and discrimination. A precise combination of mythical and lifelike features makes foker a relatable, yet universal story, appealing to a larger audience. Its relatedness to the discourse, however, leaves a chance for the theme to go back to its original superhero content and form.

\section{CONCLUSIONS}

The multimodal discourse of Batman can be viewed as a general framework comprised of several media discourses: comics discourse, film discourse, video game discourse, animation discourse, etc., as well as minor 'author' Batman discourses. The core of the discourse is formed by comics, cinema, animation and video games, while fiction and audio plays stay at the periphery. Major changes that happen in the core affect the way the character is presented in all the other texts. 
Batman discourse is comprised of texts about Batman, with the elements of the texts being in constant dynamic process of intersecting and influencing each other, and secondly, as the process of recoding of the discourse's meanings in the emerging texts. The recoding of meanings is caused by the demand of a new, more up-to-date look at the old texts and themes which results in perpetual reinterpretation and reshuffling of the same events.

A Batman text is an interpretation of the myth of Batman, which is reestablished in a particular context or situation, or reformulated in terms of the individual style of the author. With each generation, the norms and standards of interpretation may vary, bringing to the fore the present-day needs and vision of the audience.

The popularity of the discourse can be accounted for by the following:

1) use of cutting-edge technologies and multimodal designs and templates;

2) intertextuality and interactivity. As there is no prototext, the discourse allows different authors to express their vision of the character without formidable limitations. All the texts are equal in terms of the originality of plot and set of characters, as well as their impact on the dis course. Intertextuality serves to unite various texts into one discourse, signalling that the stories and their interpretations may be different, but the characters are the same;

3) relatability. The history of the discourse shows a steady shift from the highly artificial Batman's superhero world of the early comic books to a more relatable, psychologically deep and highly motivated contemporary. The maintained sense of place echoes with the real world of today, while the conflicts more often than not resemble the modern political and social agenda. The concept of relatability is then understood as the ability of the narrative to evoke in the minds of its audience a strong feeling of identification with the characters grounded in the generally recognizable contexts and situations.

\section{References}

[GameSpot]. (2012, May 24). Voice Talent - Batman: Arkham City Behind the Scenes Video [Video File]. Retrieved from https://www.youtube.com/watch? $\mathrm{v}=$ PnkcZF34SE0

[Warner Bros. Entertainment]. (2013, February 6). Batman: Year One / Heart of Vengeance: Returning Batman To His Roots / Warner Bros. Entertainment [Video File]. Retrieved from https://www.youtube.com/watch?v=lh3nlAZHJ0A 
[Warner Bros. Entertainment]. (2020, April 20). Foker / Behind The Scenes with Joaquin Phoenix and Todd Phillips / Warner Bros. Entertainment [Video File]. Retrieved from https://www.youtube.com/watch?time_continue $=1342 \& v=c L V N-$ J50vCDI\&feature $=$ emb_logo

Ackerman, S. (2008). Batman's Dark Knight Reflects Cheney Policy: Joker's Senseless, Endless Violence Echoes Al Qaeda. The Washington Independent. Reposted at https://newsgrist.typepad.com/underbelly/2008/07/the-hero-we-des.html? utm_source=feedburner\&utm_medium =feed\&utm_campaign=Feed $\% 3 A+$ type pad\%2Fnewsgrist $\% 2$ Funderbelly+\%28NEWSgrist+-+where+spin+is+art $\% 29$

Asay, P. (2012). God on the Streets of Gotham. What the Big Screen Batman Can Teach Us about God and Ourselves. Illinois: Tyndale house publishers, inc.

Azzarello, B. \& Bermejo, L. (2019). Batman: Damned. Burbank, California: DC Comics

Bakhtin, M. (1984). Rabelais and His World. Indiana: Indiana University Press

Barr, M., Roy, A. \& O’Neil, D. (1987). Detective Comics Vol. 1 \#572. Burbank, California: DC Comics

Barthes, R. (1977). Image Music Text. London: Fontana Press

Barthes, R. (1996). Mythologies. Moscow: Publishing house named Sabashnikovs (in Russian)

Bektemirov, F. (2019). Gotham, Resident Evil. The Art of Cinema, (9/10), 36-44.

Brooker, W. (2012, July 19). The Dark Knight Rises. Times Higher Education (THE). Retrieved from www.timeshighereducation.com/features/culture/the-darkknight-rises/420 605.article

Brooker, W. (2012). Hunting the Dark Knight: Twenty-First Century Batman. New York: I. B. Tauri s\& Co Ltd

Busiek, K., Dini, P., Gaiman, N., Krueger, J., Lee, S., Moore, A., Nicieza, F., Shooter, J., Simone, G., Smith, K., et al. (2001). Heroes: The World's Greatest Super Hero Creators Honor The World's Greatest Heroes 9-11-2001. New York: Marvel Comics

Campbell, J. (2004). The Hero with A Thousand Faces. Princeton and Oxford: Princeton University Press

Dozier, W. (1966-1968). Batman. New York City, ABC: Greenway Productions, 20th Century Fox Television

Goldberg, J. \& Hillhouse, J. (Producers). (2012). The fourney of Bruce Wayne [Supplements for 'The Dark Knight Rises']. United States of America: Warner Bros. Entertainment, Inc.

Gorelikov, A. (2019). Joker, between cinema and circus. Art of cinema, (9/10), 20-28.

Guber P., Peters J. (Producers), \& Burton, T. (Director). (1989). Batman. United States of America: Warner Bros. Pictures

Hill, S. (2009). Batman: Arkham Asylum. London: Rocksteady Studios

Hill, S. (2011). Batman: Arkham City. London: Rocksteady Studios 
Hill, S. (2015). Batman: Arkham Knight. London: Rocksteady Studios

Holmes, E. \& Richer, B. (2013). Batman: Arkham Origins. Montréal: WB Games Montréal

Hull, R. (Producer). (2008). Batman Unmasked: The Psychology Of The Dark Knight [Supplements for 'The Dark Knight']. United States of America: Warner Bros. Entertainment, Inc.

Ip, J. (2011). The Dark Knight's War on Terrorism. Ohio State fournal of Criminal Law. Retrieved from https://core.ac.uk/download/pdf/159590 487.pdf

Kane, B. \& Finger, B. (1939). Detective Comics Vol. 1 \#27. Burbank, California: DC Comics

Kane, B. \& Finger, B. (1939). Detective Comics Vol. 1 \#33. Burbank, California: DC Comics

Kane, B. \& Finger, B. (1940). Batman \#1. Burbank, California: DC Comics

Kane, B. \& Finger, B. (1940). Batman \#4. Burbank, California: DC Comics

Kozlov, E. V. (1999) Communicativeness of comics in the textual and semiotic aspects. PhD Thesis. Volgograd. (in Russian)

Langley, T. (2012). Batman and Psychology: A Dark and Stormy Knight. New Jersey, Hoboken: John Wiley \& Sons, Inc.

Lin, D., Lord, P., Miller, C., Lee, R. (Producers), \& McKay, C. (Director). (2017). The Lego Batman Movie. United States of America: Warner Bros. Pictures

Loeb, J. \& Lee, J. (2003). Batman: Hush. Burbank, California: DC Comics

Losev, A. F. (1996). The mythology of the Greeks and Romans. Moscow: Thought (in Russian)

Losev, A.F. (1990). Dialectics of myth. Moscow: Truth (in Russian)

MacDowell, J. (2013). Happy Endings in Hollywood Cinema. Edinburgh: Edinburgh University Press Ltd

MacGregor-Scott, P. (Producer), \& Schumacher, J. (Director). (1997). Batman \& Robin. United States of America: Warner Bros. Pictures

McCloud, S. (1994). Understanding Comics: The Invisible Art. New York: Harper Perennial

McGowan, T. (2015). Stumbling Over the Superhero: Christopher Nolan's Victories and Compromises. In J. Furby \& S. Joy (Eds.). The Cinema of Christopher Nolan (pp. 164-175). New York: Columbia University Press

McKee, R. (1997) Story. Substance, Structure, Style, and the Principles of Screenwriting. New York: ReganBooks An Imprint of HarperCollins Publishers

Milchan, A. (Producer), \& Scorsese, M. (Director). (1982). The King of Comedy. United States of America: 20th Century Fox.

Miller, F. \& Mazzucchelli, D. (1987). Batman: Year One. Burbank, California: DC Comics 
Moore, A. \& Bolland, B. (1988). Batman: The Killing foke. Burbank, California: DC Comics

Morrison, G. (2010). Batman: R.I.P. Burbank, California: DC Comics

Mudle, K. \& Stauder, J. (2016) Batman: The Telltale Series. San Rafael, California: Telltale Games

Murphy, S. (2018). Batman: White Knight. Burbank, California: DC Comics

Nolan, C., Thomas E. \& Roven C. (Producers), \& Nolan, C. (Director). (2008). The Dark Knight. United States of America: Warner Bros. Pictures

Nolan, C., Thomas E., Roven C. \& Franco L. (Producers), \& Nolan, C. (Director). (2005). Batman Begins. United States of America: Warner Bros. Pictures

Pheasant-Kelly, F. (2015). Representing Trauma: Grief, Amnesia and Traumatic Memory in Nolan's New Millenial Films. In J. Furby \& S. Joy (Eds.). The Cinema of Christopher Nolan (pp. 99-120). New York: Columbia University Press

Phillips, T. (Producer), \& Phillips, T. (Director). (2019). foker. United States of America: Warner Bros. Pictures

Round, J. (2014). Gothic in Comics and Graphic Novels: A Critical Approach. Jefferson, North Carolina: McFarland \& Company

Schopp, A. (2009). Interrogating the Manipulation of Fear: V for Vendetta, Batman Begins, Good Night, and Good Luch, and America's "War on Terror". In A. Schopp (Ed.). The War on Terror and American Popular Culture: September 11 and Beyond (pp. 259-287). Madison, New Jersey: Fairleigh Dickinson Univ Press

Sharipina, T.A. (2007). Perception of antiquity in the literary consciousness of Germany in the XX century (the Trojan cycle of myths). Doctoral Dissertation. Moscow (in Russian)

Shklovsky, V. B. (1925). Art as a device. In Theory of prose (pp. 7-20). Moscow: Krug (in Russian)

Slyshkin G. G. \& Efremova M. A. (2004). Filmtext (experience of linguocultural analysis). Moscow: Aquarius Publishers (in Russian)

Snyder, S. \& Capullo, G. (2013). Batman: Death of the Family. Burbank, California: DC Comics

Snyder, S. \& Paquette, Y. (2016). Batman \#49. Burbank, California: DC Comics

Sonin, A.G. (2006). Modeling the mechanisms of understanding polycode texts. Doctoral Dissertation. Moscow (in Russian)

Sorokin, Yu.A. \& Tarasov, E.F. (1990). Creolized texts and their communicative function. In Optimization of speech impact (pp. 180-186). Moscow: Nauka (in Russian)

Spiegelman, A. (1996). The Complete Maus. New York: Pantheon

Spiegelman, A. (2004). In the Shadow of No Towers. New York: Random House 
Starlin, J., Aparo, J. \& O'Neil, D. (1988). Batman: A Death in the Family. Burbank, California: DC Comics

Straczynski, M. J. (2001). The Amazing Spider-Man Vol.2 \#36. New York: Marvel Comics

Talal, A. (2019). Myth and Life in Cinema: Meanings and Instruments of Dramatic Language. Moscow: Alpina non-fiction (in Russian)

Timm, B. \& Radomski, E. (1992-1995). Batman: The Animated Series. United States of America: Warner Bros.

Toh, J. (2010). The Tools and Toys of (the) War (on Terror): Consumer Desire, Military Fetish, and Regime Change in Batman Begins. In J. Birkenstein, A. Froula \& K. Randell (Eds.). Reframing 9/11. Film, Popular Culture and the "War on Terror" (pp. 127-141). New York: The Continuum International Publishing Group Inc.

Tsvetkov, A. (2019) Chaos and anarchy. Art of cinema, (9/10), 45-51. (in Russian)

Uricchio, W. \& Pearson, R. (1991). The Many Lives of the Batman: Critical Approaches to a Superhero and His Media. London: BFI Publishing

Vogler, C. (1998). The Writer's fourney. Mythic Structure for Writers. Studio City, CA: Michael Wiese Productions

Zaretskaya, A.N. (2010). Features of the implementation of subtext in film discourse. PhD Thesis. Chelyabinsk (in Russian)

\section{Список литературы}

[GameSpot]. (2012, May 24). Voice Talent - Batman: Arkham City Behind the Scenes Video [Video File]. Retrieved from https://www.youtube.com/watch? $\mathrm{v}=$ PnkcZF34SE0

[Warner Bros. Entertainment]. (2013, February 6). Batman: Year One / Heart of Vengeance: Returning Batman To His Roots / Warner Bros. Entertainment [Video File]. Retrieved from https://www.youtube.com/watch?v=lh3nlAZHJ0A

[Warner Bros. Entertainment]. (2020, April 20). Joker / Behind The Scenes with Joaquin Phoenix and Todd Phillips / Warner Bros. Entertainment [Video File]. Retrieved from https://www.youtube.com/watch?time_continue $=1342 \& v=c L V N-$ J50vCDI\&feature $=$ emb_logo

Ackerman, S. (2008). Batman's Dark Knight Reflects Cheney Policy: Joker's Senseless, Endless Violence Echoes Al Qaeda. The Washington Independent. Reposted at https://newsgrist.typepad.com/underbelly/2008/07/the-hero-we-des.html? utm_source=feedburner\&utm_medium=feed\&utm_campaign=Feed\%3A+typepad\%2Fnewsgrist $\% 2$ Funderbelly+\%28NEWSgrist+-+where+spin+is+art $\% 29$

Asay, P. (2012). God on the Streets of Gotham. What the Big Screen Batman Can Teach Us about God and Ourselves. Illinois: Tyndale house publishers, inc.

Azzarello, B. \& Bermejo, L. (2019). Batman: Damned. Burbank, California: DC Comics

Bakhtin, M. (1984). Rabelais and His World. Indiana: Indiana University Press 
Barr, M., Roy, A. \& O’Neil, D. (1987). Detective Comics Vol. 1 \#572. Burbank, California: DC Comics

Barthes, R. (1977). Image Music Text. London: Fontana Press

Brooker, W. (2012). Hunting the Dark Knight: Twenty-First Century Batman. New York: I. B. Tauri s\& Co Ltd

Brooker, W. (2012, July 19). The Dark Knight Rises. Times Higher Education (THE). Retrieved from www.timeshighereducation.com/features/culture/the-darkknight-rises/420 605.article

Busiek, K., Dini, P., Gaiman, N., Krueger, J., Lee, S., Moore, A., Nicieza, F., Shooter, J., Simone, G., Smith, K., et al. (2001). Heroes: The World's Greatest Super Hero Creators Honor The World's Greatest Heroes 9-11-2001. New York: Marvel Comics

Campbell, J. (2004). The Hero with A Thousand Faces. Princeton and Oxford: Princeton University Press

Dozier, W. (1966-1968). Batman. New York City, ABC: Greenway Productions, 20th Century Fox Television

Goldberg, J. \& Hillhouse, J. (Producers). (2012). The fourney of Bruce Wayne [Supplements for 'The Dark Knight Rises']. United States of America: Warner Bros. Entertainment, Inc.

Guber P., Peters J. (Producers), \& Burton, T. (Director). (1989). Batman. United States of America: Warner Bros. Pictures

Hill, S. (2009). Batman: Arkham Asylum. London: Rocksteady Studios

Hill, S. (2011). Batman: Arkham City. London: Rocksteady Studios

Hill, S. (2015). Batman: Arkham Knight. London: Rocksteady Studios

Holmes, E. \& Richer, B. (2013). Batman: Arkham Origins. Montréal: WB Games Montréal

Hull, R. (Producer). (2008). Batman Unmasked: The Psychology Of The Dark Knight [Supplements for 'The Dark Knight']. United States of America: Warner Bros. Entertainment, Inc.

Ip, J. (2011). The Dark Knight's War on Terrorism. Ohio State Journal of Criminal Law. Retrieved from https://core.ac.uk/download/pdf/159590487.pdf

Kane, B. \& Finger, B. (1939). Detective Comics Vol. 1 \#27. Burbank, California: DC Comics

Kane, B. \& Finger, B. (1939). Detective Comics Vol. 1 \#33. Burbank, California: DC Comics

Kane, B. \& Finger, B. (1940). Batman \#1. Burbank, California: DC Comics

Kane, B. \& Finger, B. (1940). Batman \#4. Burbank, California: DC Comics

Langley, T. (2012). Batman and Psychology: A Dark and Stormy Knight. New Jersey, Hoboken: John Wiley \& Sons, Inc. 
Lin, D., Lord, P., Miller, C., Lee, R. (Producers), \& McKay, C. (Director). (2017). The Lego Batman Movie. United States of America: Warner Bros. Pictures

Loeb, J. \& Lee, J. (2003). Batman: Hush. Burbank, California: DC Comics

MacDowell, J. (2013). Happy Endings in Hollywood Cinema. Edinburgh: Edinburgh University Press Ltd

MacGregor-Scott, P. (Producer), \& Schumacher, J. (Director). (1997). Batman \& Robin. United States of America: Warner Bros. Pictures

McCloud, S. (1994). Understanding Comics: The Invisible Art. New York: Harper Perennial

McGowan, T. (2015). Stumbling Over the Superhero: Christopher Nolan's Victories and Compromises. In J. Furby \& S. Joy (Eds.). The Cinema of Christopher Nolan (pp. 164-175). New York: Columbia University Press

McKee, R. (1997) Story. Substance, Structure, Style, and the Principles of Screenwriting. New York: ReganBooks An Imprint of HarperCollins Publishers

Milchan, A. (Producer), \& Scorsese, M. (Director). (1982). The King of Comedy. United States of America: 20th Century Fox.

Miller, F. \& Mazzucchelli, D. (1987). Batman: Year One. Burbank, California: DC Comics

Moore, A. \& Bolland, B. (1988). Batman: The Killing foke. Burbank, California: DC Comics

Morrison, G. (2010). Batman: R.I.P. Burbank, California: DC Comics

Mudle, K. \& Stauder, J. (2016) Batman: The Telltale Series. San Rafael, California: Telltale Games

Murphy, S. (2018). Batman: White Knight. Burbank, California: DC Comics

Nolan, C., Thomas E. \& Roven C. (Producers), \& Nolan, C. (Director). (2008). The Dark Knight. United States of America: Warner Bros. Pictures

Nolan, C., Thomas E., Roven C. \& Franco L. (Producers), \& Nolan, C. (Director). (2005). Batman Begins. United States of America: Warner Bros. Pictures

Pheasant-Kelly, F. (2015). Representing Trauma: Grief, Amnesia and Traumatic Memory in Nolan's New Millenial Films. In J. Furby \& S. Joy (Eds.). The Cinema of Christopher Nolan (pp. 99-120). New York: Columbia University Press

Phillips, T. (Producer), \& Phillips, T. (Director). (2019). foker. United States of America: Warner Bros. Pictures

Round, J. (2014). Gothic in Comics and Graphic Novels: A Critical Approach. Jefferson, North Carolina: McFarland \& Company

Schopp, A. (2009). Interrogating the Manipulation of Fear: V for Vendetta, Batman Begins, Good Night, and Good Luch, and America's "War on Terror". In A. Schopp (Ed.). The War on Terror and American Popular Culture: September 11 and Beyond (pp. 259-287). Madison, New Jersey: Fairleigh Dickinson Univ Press

Snyder, S. \& Capullo, G. (2013). Batman: Death of the Family. Burbank, California: DC Comics

Snyder, S. \& Paquette, Y. (2016). Batman \#49. Burbank, California: DC Comics 
Spiegelman, A. (1996). The Complete Maus. New York: Pantheon

Spiegelman, A. (2004). In the Shadow of No Towers. New York: Random House

Starlin, J., Aparo, J. \& O'Neil, D. (1988). Batman: A Death in the Family. Burbank, California: DC Comics

Straczynski, M. J. (2001). The Amazing Spider-Man Vol.2 \#36. New York: Marvel Comics

Timm, B. \& Radomski, E. (1992-1995). Batman: The Animated Series. United States of America: Warner Bros.

Toh, J. (2010). The Tools and Toys of (the) War (on Terror): Consumer Desire, Military Fetish, and Regime Change in Batman Begins. In J. Birkenstein, A. Froula \& K. Randell (Eds.). Reframing 9/11. Film, Popular Culture and the "War on Terror" (pp. 127-141). New York: The Continuum International Publishing Group Inc.

Uricchio, W. \& Pearson, R. (1991). The Many Lives of the Batman: Critical Approaches to a Superhero and His Media. London: BFI Publishing

Vogler, C. (1998). The Writer's Fourney. Mythic Structure for Writers. Studio City, CA: Michael Wiese Productions

Барт, Р. (1996). Мифологии. Москва: Изд-во им. Сабашниковых.

Бектемиров, Ф. (2019). Готэм, обитель зла. Искусство кино, (9/10), 36-44.

Гореликов, А. (2019). Джокер между кино и цирком. Искусство кино, (9/10), 20-28.

Зарецкая, А. Н. (2010). Особенности реализации подтекста в кинодискурсе. $P h D$ Thesis. Челябинск.

Козлов, Е. В. (1999). Коммуникативность комикса в текстуальном и семиотическом аспектах. PhD Thesis. Волгоград

Лосев, А. Ф. (1990). Диалектика мифа. Москва: Правда.

Лосев, А. Ф. (1996). Мифология греков и римлян. Москва: Мысль.

Слышкин Г. Г. \& Ефремова М. А. (2004). Кинотекст (опыт лингвокультурологического анализа). Москва: Водолей Publishers

Сонин, А. Г. (2006). Моделирование механизмов понимания поликодовых текстов. Doctoral Dissertation. Москва.

Сорокин, Ю. А. \& Тарасов, Е. Ф. (1990). Креолизованные тексты и их коммуникативная функция. В Оптимизация речевого воздействия ( стр. 180-186). Москва: Наука

Талал, А. (2019). Миф и жизнь в кино: Смысль и инструменты драматургического языка. Москва: Альпина нон-фикшн.

Цветков, А. (2019) Хаос и анархия. Искусство кино, (9/10), 45-51.

Шарипина, Т. А. (2007). Восприятие античности в литературном сознании Германии XX века (троянский цикл мифов). Doctoral Dissertation. Москва.

Шкловский, В. Б. (1925). Искусство как приём. В О теории прозы (стр. 7-20). Москва: Круг. 